\title{
Identification of Bioactive Small Molecule Inhibitors of Separase
}

Lars Henschke ${ }^{1}$, Matthias Frese ${ }^{2}$, Susanne Hellmuth ${ }^{3}$, Andreas Marx², Olaf Stemmann², Thomas U. Mayer ${ }^{1}$

\section{${ }^{1}$ Department of Biology and Konstanz Research School Chemical-Biology (KoRS-CB), University of} Konstanz, Universitätsstraße. 10, 78467 Konstanz, Germany

${ }^{2}$ Department of Chemistry and Konstanz Research School Chemical-Biology (KoRS-CB), University of Konstanz, Universitätsstraße. 10, 78467 Konstanz, Germany

${ }^{3}$ Department of Genetics, University of Bayreuth, Universitätsstraße 30, 95440 Bayreuth, Germany

\section{Contents}

1. Supplementary Figures

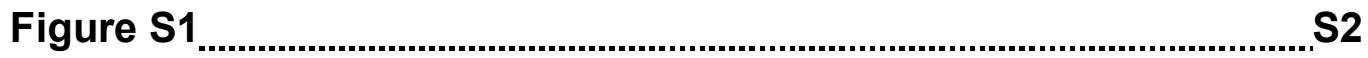

Figure S2

Table S1

Figure S3

Figure S4

Figure S5

Figure S6

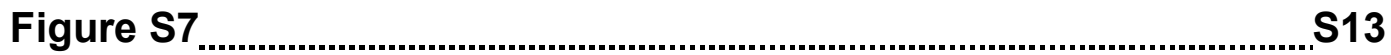

Figure S8

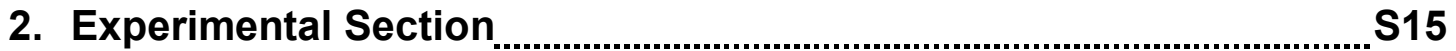

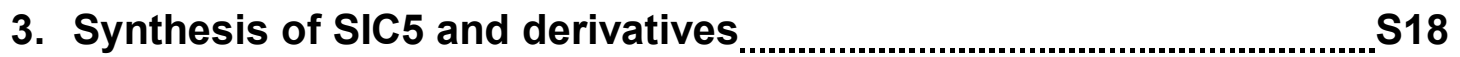

4. Characterization of SIC1-4 \& Sepin-1 .............................................. S23

5. NMR Spectra

6. References 


\section{Supplementary Figures}

A

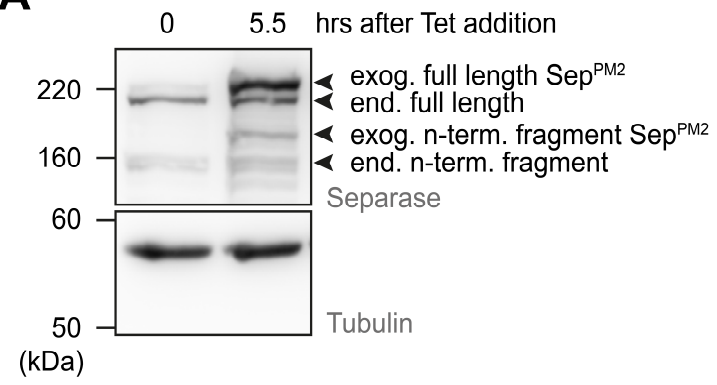

B

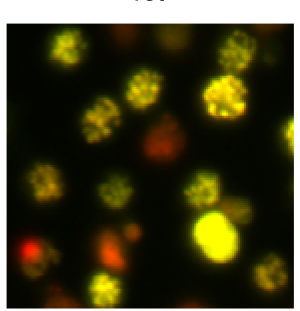

+ Tet

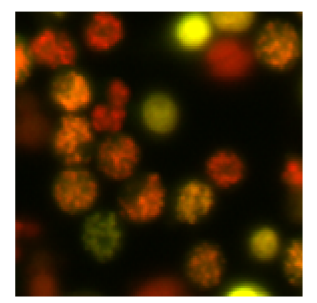

Figure S1: High throughput screening for separase inhibitors. (A) Western blot analyses of HEK293 cells before and after tetracycline (Tet) addition to induce the expression of ectopic separase $^{\mathrm{PM} 2}$ fused to six Myc-tags. (B) Exemplary images of cells expressing the separase sensor together with (+Tet) or not (-Tet) ectopic Myc-separase ${ }^{\mathrm{PM} 2}$. Image algorithms were applied to calculate the hue value of the mCherry and eGFP signal for each mitotic cell as readout for separase activity.
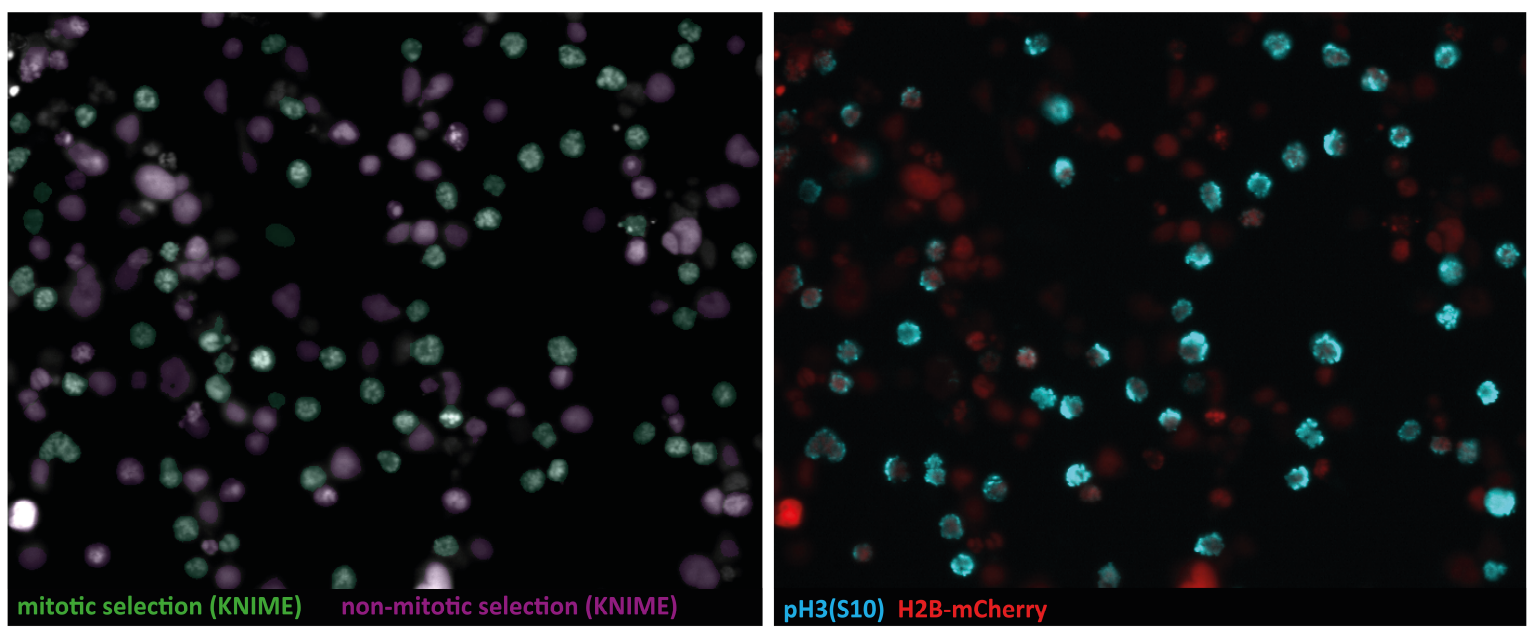

Figure S2: Validation of automated cell segmentation and classification algorithms (KNIME). Left panel shows an exemplary image analyzed by the KNIME algorithm, which uses the structure of chromatin to classify mitotic cells. Cells identified as mitotic cells are labeled in green, non-mitotic cells in purple. Right panel shows the identical image stained for the mitotic marker phosphorylated histone $\mathrm{H} 3(\mathrm{pH} 3(\mathrm{~S} 10))$. $\mathrm{pH} 3(\mathrm{~S} 10)$ positive cells are shown in cyan. The accuracy of the KNIME algorithm to detect mitotic cells was calculated to be $80 \%$. 


\begin{tabular}{|c|c|}
\hline Screening Plate & $Z^{\prime}$ value \\
\hline 151119-001-CDI-101 & 0.659 \\
\hline 151119-002-CDI-102 & 0.739 \\
\hline 151119-003-CDI-103 & 0.664 \\
\hline 151119-004-CDI-104 & 0.669 \\
\hline 151203-001-CDI-105 & 0.767 \\
\hline 151203-002-CDI-106 & 0.695 \\
\hline 151203-003-CDI-107 & 0.692 \\
\hline 151203-004-CDI-108 & 0.614 \\
\hline 151203-005-CDI-109 & 0.748 \\
\hline 151203-006-CDI-110 & 0.666 \\
\hline 151218-001-CDI-111 & 0.733 \\
\hline 151218-002-CDI-112 & 0.757 \\
\hline 151218-003-CDI-113 & 0.713 \\
\hline 151218-004-CDI-114 & 0.738 \\
\hline 151218-005-CDI-115 & 0.735 \\
\hline 160122-001-CDI-116 & 0.555 \\
\hline 160122-002-CDI-117 & 0.689 \\
\hline 160122-003-CDI-118 & 0.695 \\
\hline 160122-004-CDI-119 & 0.553 \\
\hline 160122-005-CDI-120 & 0.673 \\
\hline 160128-001-MBC-008 & 0.724 \\
\hline 160128-002-MBC-009 & 0.533 \\
\hline 160128-003-MBC-019 & 0.735 \\
\hline 160203-001-CDI-122 & 0.783 \\
\hline 160203-002-CDI-123 & 0.730 \\
\hline 160203-003-CDI-124 & 0.589 \\
\hline 160203-004-CDI-125 & 0.762 \\
\hline 160203-005-CDI-126 & 0.763 \\
\hline 160203-006-CDI-127 & 0.761 \\
\hline 160205-001-CBN-P1 & 0.784 \\
\hline 160205-002-CBN-P2 & 0.763 \\
\hline 160205-003-CBN-P3 & 0.769 \\
\hline 160205-004-CBN-P4 & 0.613 \\
\hline 160205-005-CBN-P5 & 0.763 \\
\hline 160205-006-CBN-P6 & 0.758 \\
\hline 160211-001-CBN-P7 & 0.731 \\
\hline 160211-002-CBN-P8 & 0.640 \\
\hline 160211-003-CBN-P9 & 0.681 \\
\hline 160211-004-CBN-P10 & 0.757 \\
\hline 160211-005-CBN-P11 & 0.651 \\
\hline 160211-006-CBN-P12 & 0.643 \\
\hline 160213-001-CBN-P13 & 0.702 \\
\hline 160213-002-CBN-P14 & 0.640 \\
\hline 160213-003-CBN-P15 & 0.655 \\
\hline 160213-005-CBN-P17 & 0.613 \\
\hline 160218-001-CBN-P16 & 0.773 \\
\hline 160218-002-CBN-P18 & 0.747 \\
\hline 160218-003-CBN-P19 & 0.661 \\
\hline 160218-004-CBN-P20 & 0.749 \\
\hline 160218-005-CBN-P21 & 0.634 \\
\hline 160220-001-CBN-P22 & 0.781 \\
\hline 160220-002-CBN-P23 & 0.696 \\
\hline
\end{tabular}

\begin{tabular}{|c|c|}
\hline Screening Plate & $Z^{\prime}$ value \\
\hline 160220-003-CBN-P25 & 0.663 \\
\hline 160220-004-CBN-P26 & 0.741 \\
\hline 160220-005-CBN-P27 & 0.749 \\
\hline 160223-001-CBN-P24 & 0.707 \\
\hline 160223-002-CBN-P28 & 0.747 \\
\hline 160223-003-CBN-P29 & 0.788 \\
\hline 160223-004-CBN-P30 & 0.709 \\
\hline 160223-005-CBN-P31 & 0.681 \\
\hline 160223-006-CBN-P32 & 0.712 \\
\hline 160225-001-CBN-P33 & 0.771 \\
\hline 160225-002-CBN-P34 & 0.672 \\
\hline 160225-003-CBN-P35 & 0.610 \\
\hline 160225-004-CBN-P36 & 0.742 \\
\hline 160225-005-CBN-P37 & 0.772 \\
\hline 160225-006-CBN-P38 & 0.654 \\
\hline 160227-001-CBN-P39 & 0.808 \\
\hline 160227-002-CBN-P40 & 0.687 \\
\hline 160227-003-CBN-P41 & 0.744 \\
\hline 160227-004-CBN-P42 & 0.772 \\
\hline 160227-005-CBN-P43 & 0.643 \\
\hline 160227-006-CBN-P44 & 0.670 \\
\hline 160303-001-CBN-P45 & 0.732 \\
\hline 160303-002-CBN-P46 & 0.655 \\
\hline 160303-003-CBN-P47 & 0.698 \\
\hline 160303-004-CBN-P48 & 0.665 \\
\hline 160303-005-CBN-P1001 & 0.641 \\
\hline 160305-001-CBN-P1002 & 0.797 \\
\hline 160305-002-CBN-P1003 & 0.764 \\
\hline 160305-003-CBN-P1004 & 0.781 \\
\hline 160305-004-CBN-P1005 & 0.759 \\
\hline 160305-005-CBN-P1006 & 0.729 \\
\hline 160305-006-CBN-P1007 & 0.735 \\
\hline 160317-001-CBN-P1008 & 0.754 \\
\hline 160317-002-CBN-P1009 & 0.683 \\
\hline 160317-003-CBN-P1010 & 0.728 \\
\hline 160317-004-MBC-001 & 0.729 \\
\hline 160317-005-MBC-002 & 0.695 \\
\hline 160317-006-MBC-003 & 0.740 \\
\hline 160318-001-MBC-004 & 0.746 \\
\hline 160318-002-MBC-005 & 0.774 \\
\hline 160318-003-MBC-006 & 0.710 \\
\hline 160318-004-MBC-007 & 0.674 \\
\hline 160318-005-MBC-010 & 0.788 \\
\hline 160318-006-MBC-011 & 0.765 \\
\hline 160324-001-MBC-012 & 0.810 \\
\hline 160324-002-MBC-013 & 0.605 \\
\hline 160324-003-MBC-014 & 0.691 \\
\hline 160324-004-MBC-015 & 0.781 \\
\hline 160324-005-MBC-016 & 0.770 \\
\hline 160324-006-MBC-017 & 0.808 \\
\hline 160325-001-MBC-018 & 0.700 \\
\hline 160325-002-MBC-020 & 0.727 \\
\hline
\end{tabular}

\begin{tabular}{|c|c|}
\hline Screening Plate & $Z^{\prime}$ value \\
\hline 160325-003-MBC-021 & 0.650 \\
\hline 160325-004-MBC-022 & 0.739 \\
\hline 160325-005-MBC-023 & 0.672 \\
\hline 160325-006-MBC-024 & 0.797 \\
\hline 160401-001-MBC-025 & 0.751 \\
\hline 160401-002-MBC-026 & 0.637 \\
\hline 160401-003-MBC-027 & 0.728 \\
\hline 160401-004-MBC-028 & 0.618 \\
\hline 160428-001-NATx-10 & 0.803 \\
\hline 160428-002-NATx-11 & 0.769 \\
\hline 160428-003-NATx-12 & 0.798 \\
\hline 160428-004-NATX-13 & 0.646 \\
\hline 160428-005-NATx-14 & 0.759 \\
\hline 160428-006-NATX-15 & 0.723 \\
\hline 160429-001-NATx-8 & 0.722 \\
\hline 160429-002-NATX-9 & 0.695 \\
\hline 160429-003-NATx-5 & 0.745 \\
\hline 160429-005-NATx-7 & 0.765 \\
\hline 160429-006-NATx-16 & 0.666 \\
\hline 160519-001-CBN-P1017 & 0.756 \\
\hline 160519-002-CBN-P1018 & 0.706 \\
\hline 160519-003-CBN-P1019 & 0.777 \\
\hline 160519-004-CBN-P1020 & 0.768 \\
\hline 160519-005-CBN-P1021 & 0.714 \\
\hline 160519-006-CBN-P1022 & 0.701 \\
\hline 160520-001-CBN-P4008 & 0.697 \\
\hline 160520-002-CBN-P4009 & 0.691 \\
\hline $160520-003-C B N-P 4010$ & 0.723 \\
\hline 160520-004-CBN-P4011 & 0.538 \\
\hline 160520-005-CBN-P4012 & 0.538 \\
\hline 160520-006-CBN-P3001 & 0.593 \\
\hline 160525-001-CBN-P3006 & 0.715 \\
\hline 160525-002-CBN-P3012 & 0.763 \\
\hline 160525-003-CBN-P1013 & 0.737 \\
\hline 160525-004-CBN-P1011 & 0.694 \\
\hline 160525-005-CBN-P1012 & 0.642 \\
\hline 160616-002-NATx-2 & 0.505 \\
\hline 160616-003-NATx-3 & 0.571 \\
\hline 160616-004-NATX-4 & 0.652 \\
\hline 160616-005-NATx-6 & 0.655 \\
\hline 160616-006-MBC-029 & 0.634 \\
\hline 160617-001-CBN-P1014 & 0.551 \\
\hline 160617-002-CBN-P1015 & 0.554 \\
\hline 160617-003-CBN-P1016 & 0.525 \\
\hline 160617-004-CDI-121 & 0.712 \\
\hline 160819-001-ICCB-204 & 0.633 \\
\hline 160819-002-ICCB-205 & 0.659 \\
\hline 160819-003-ACD-151 & 0.579 \\
\hline 160819-004-ACD-153 & 0.678 \\
\hline 160819-005-ACD-154 & 0.711 \\
\hline 161028-001-ACD-152 & 0.739 \\
\hline 161028-002-NATx-1 & 0.718 \\
\hline
\end{tabular}

Table S1: Overview of all compound plates that were tested in HTS with corresponding Z' values 
A

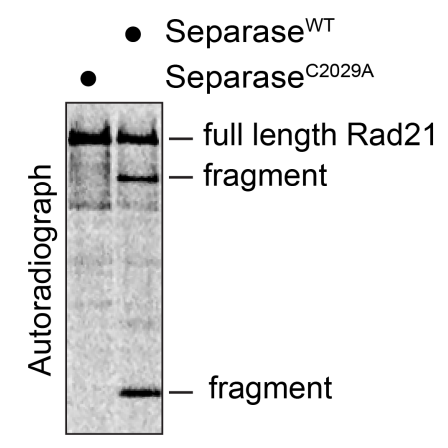


B
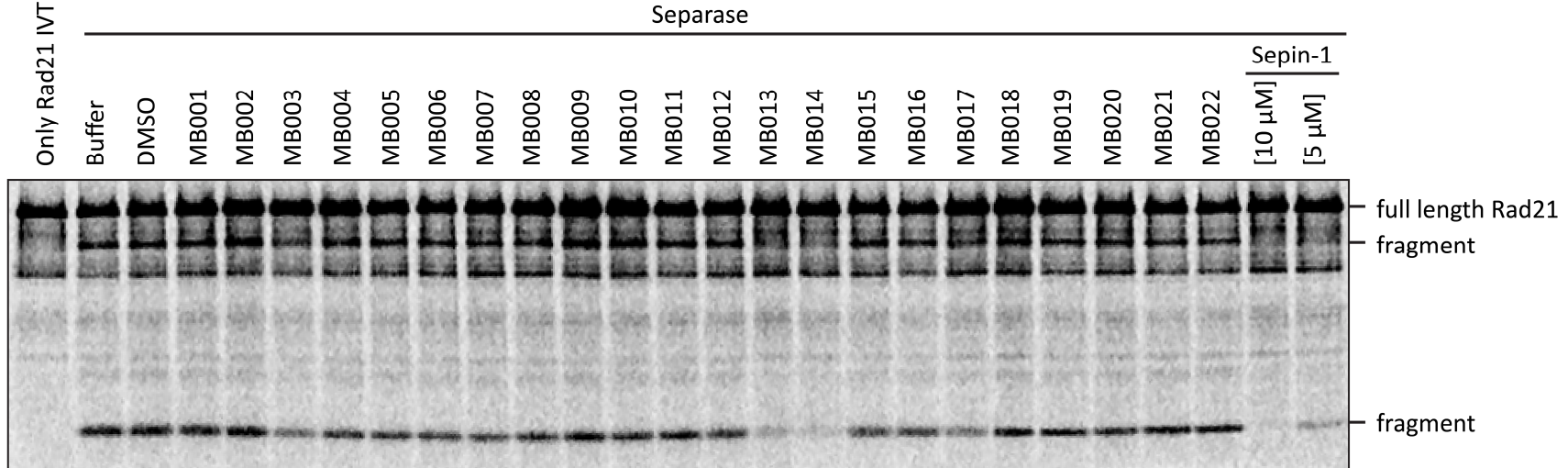

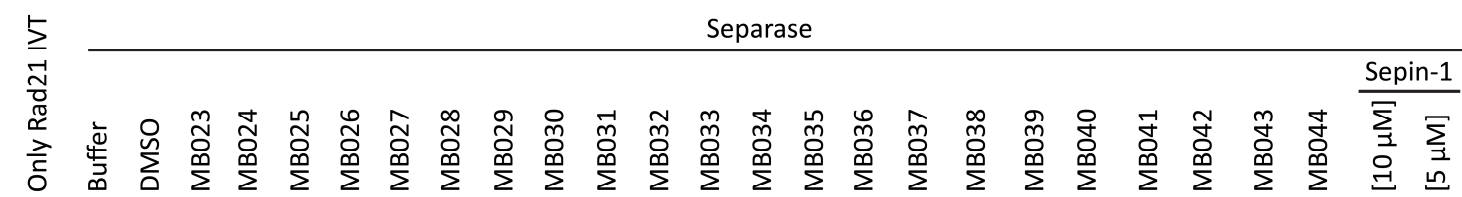

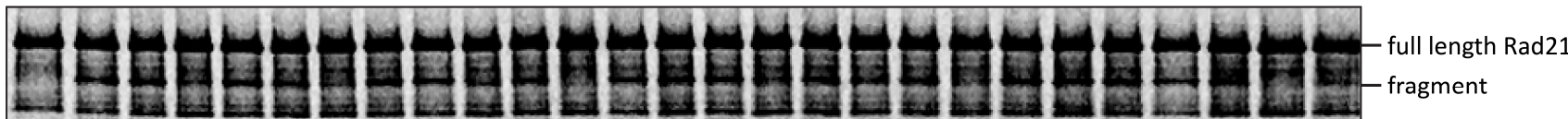

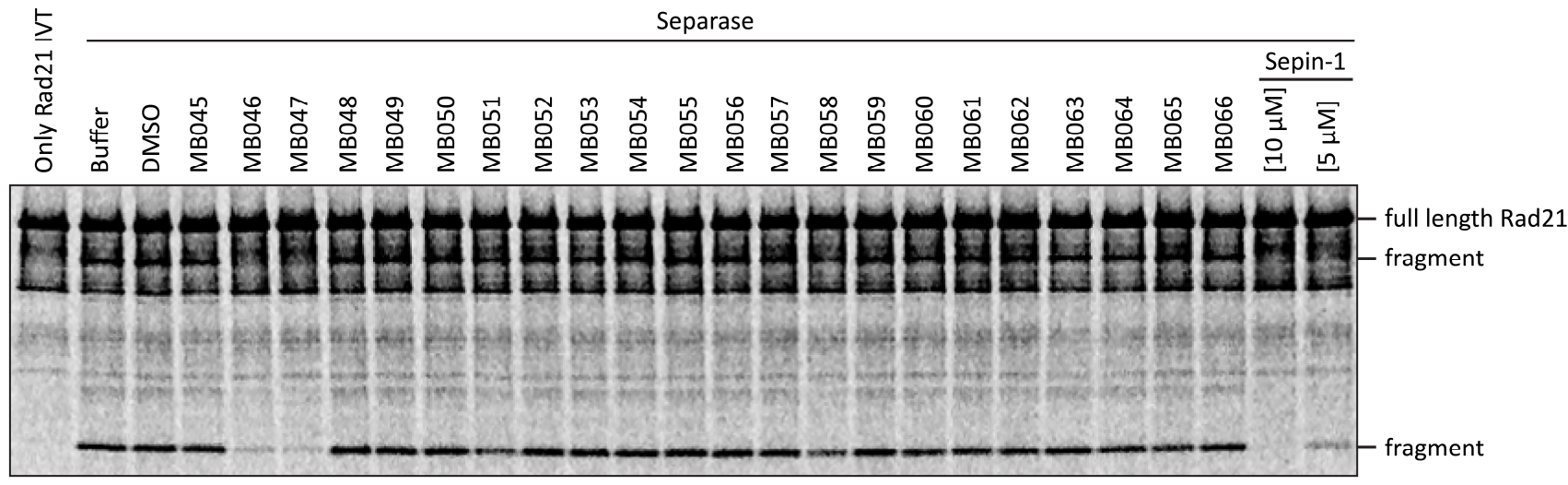

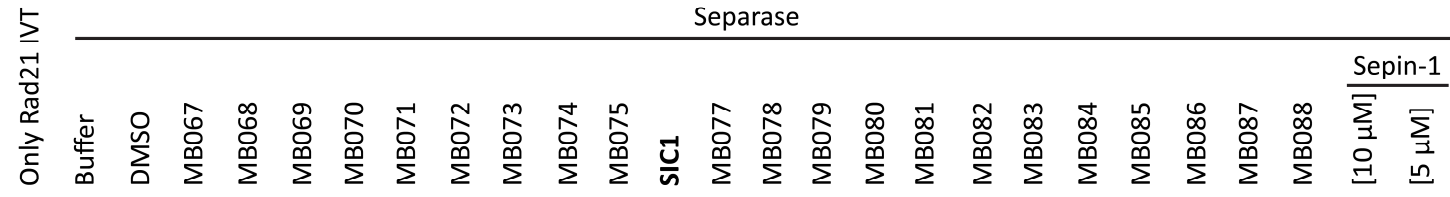

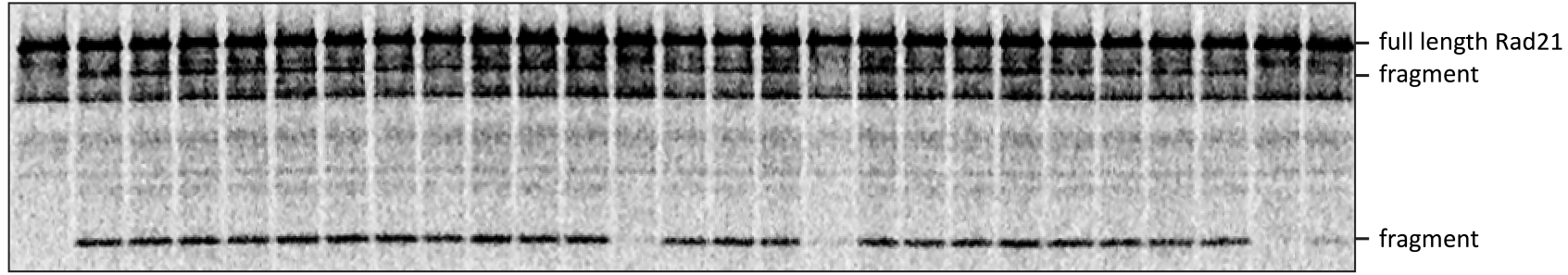



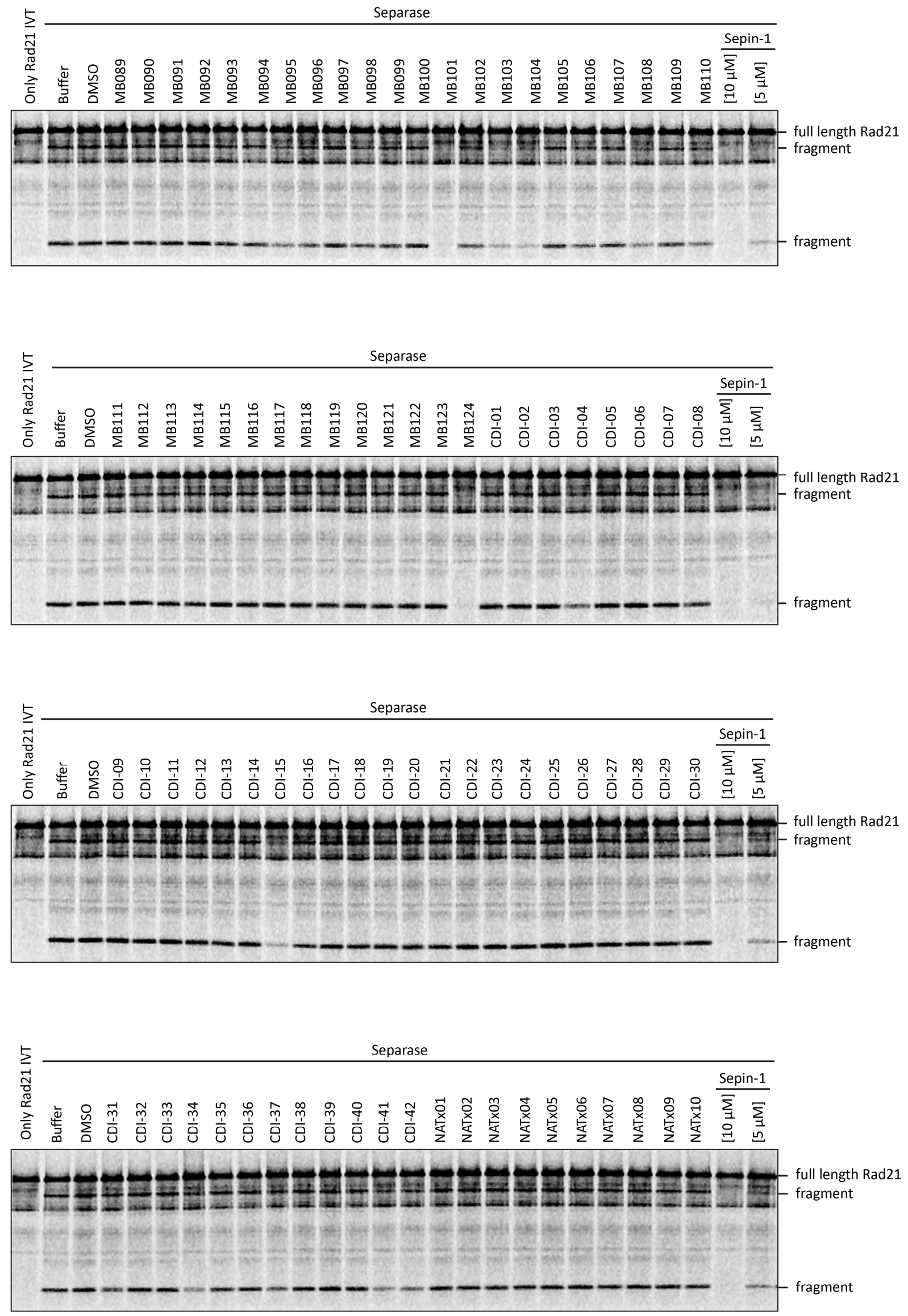

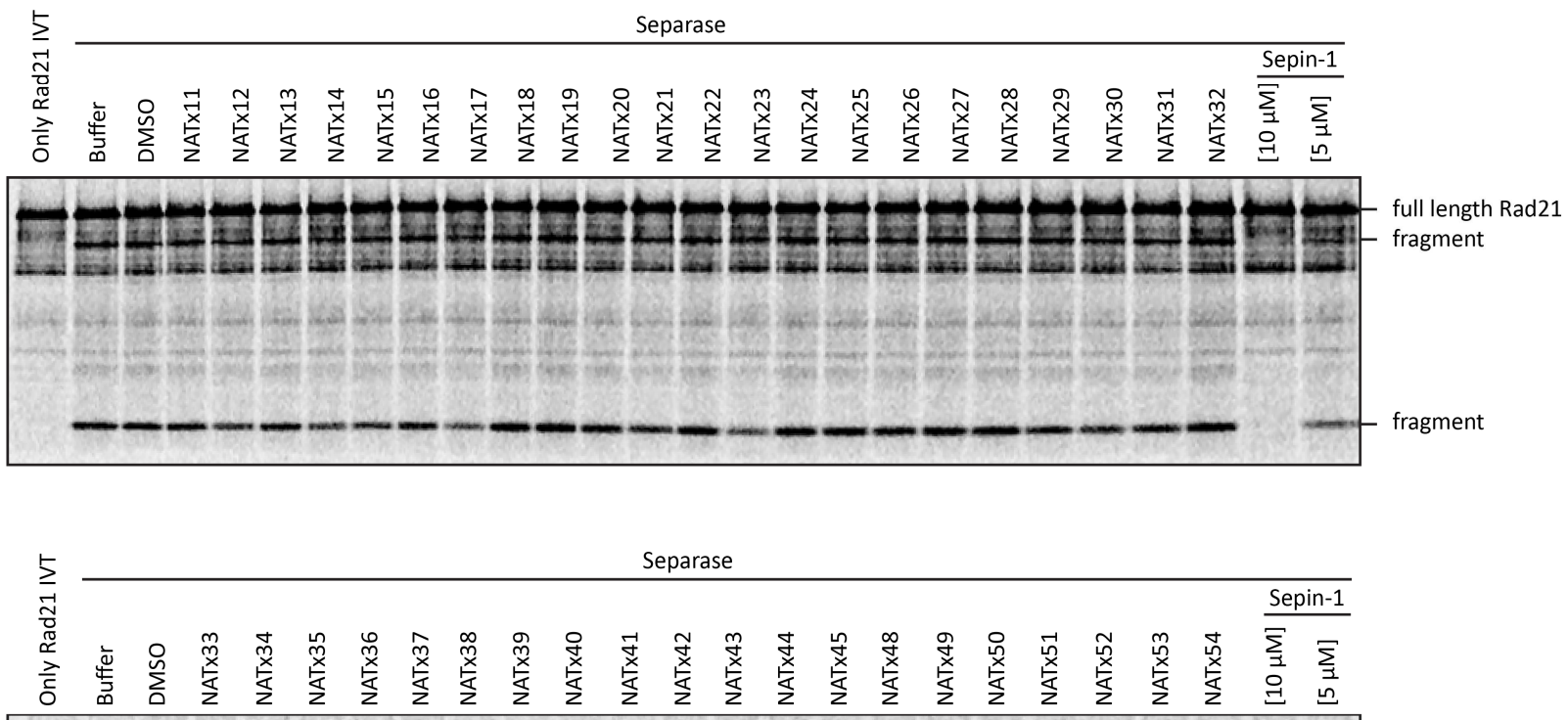

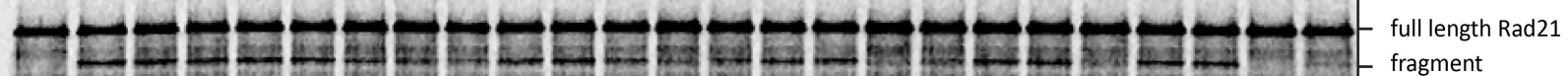

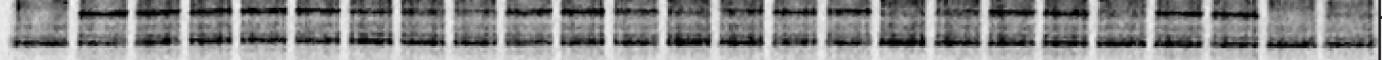
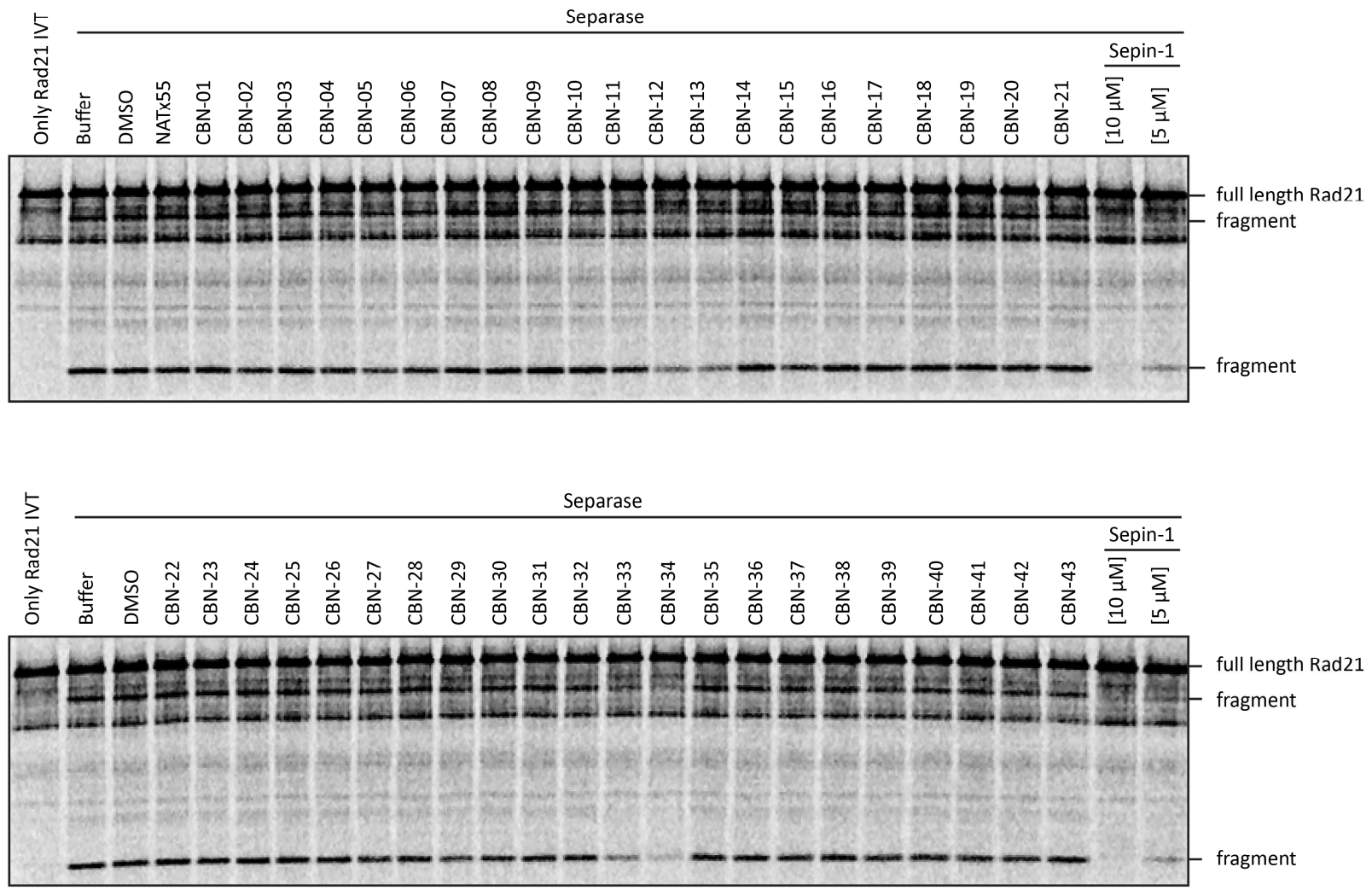

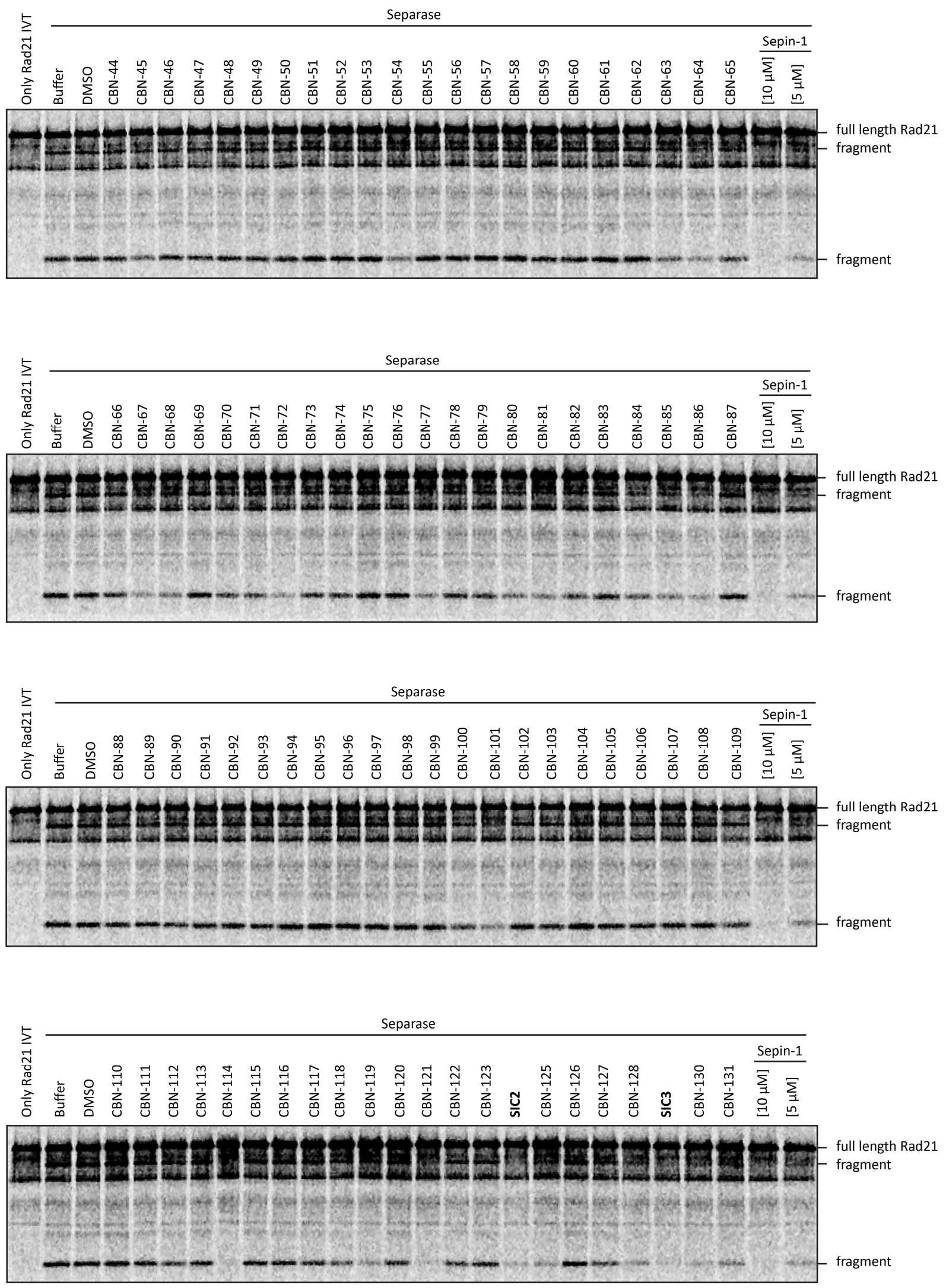

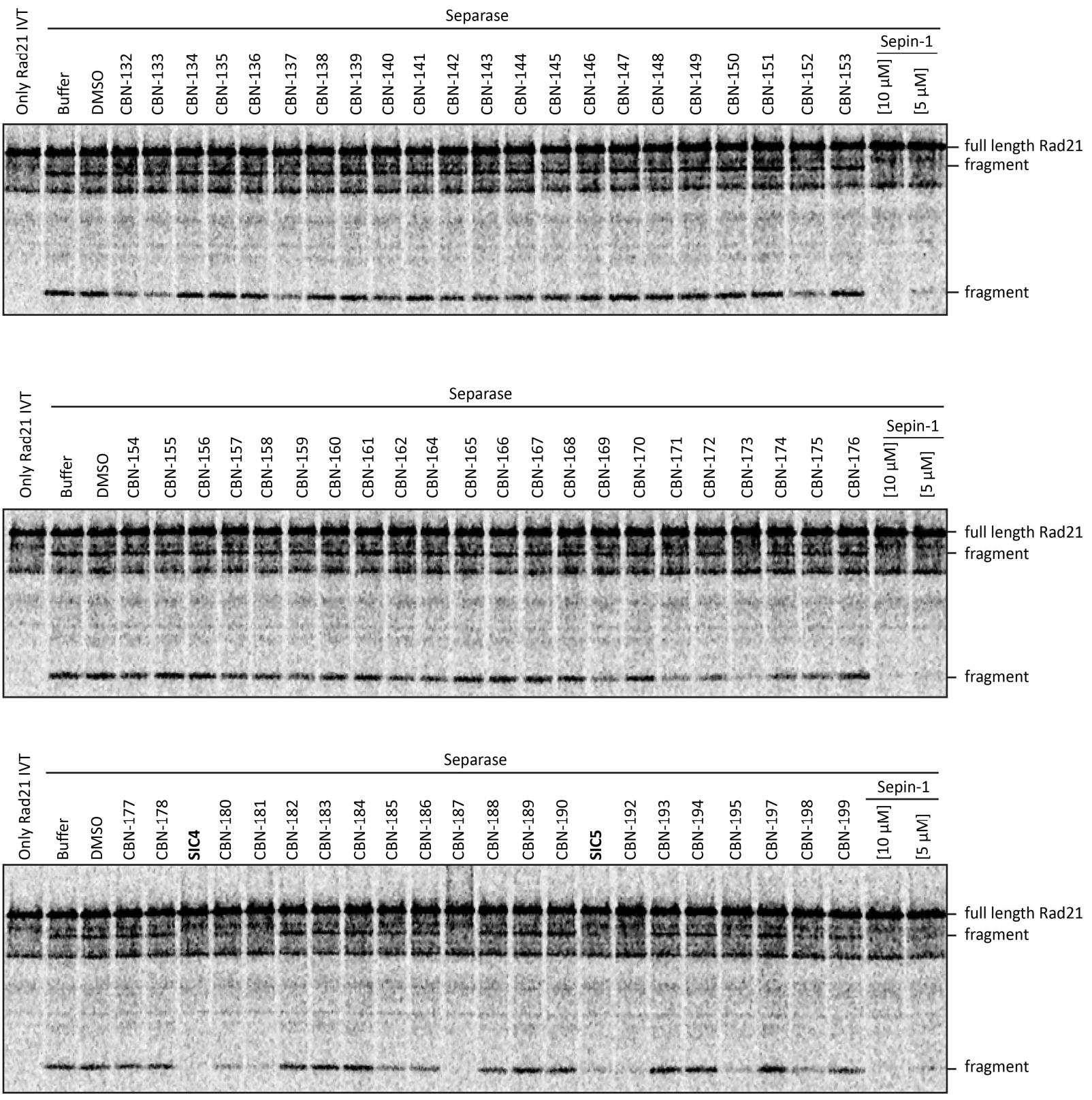

Separase

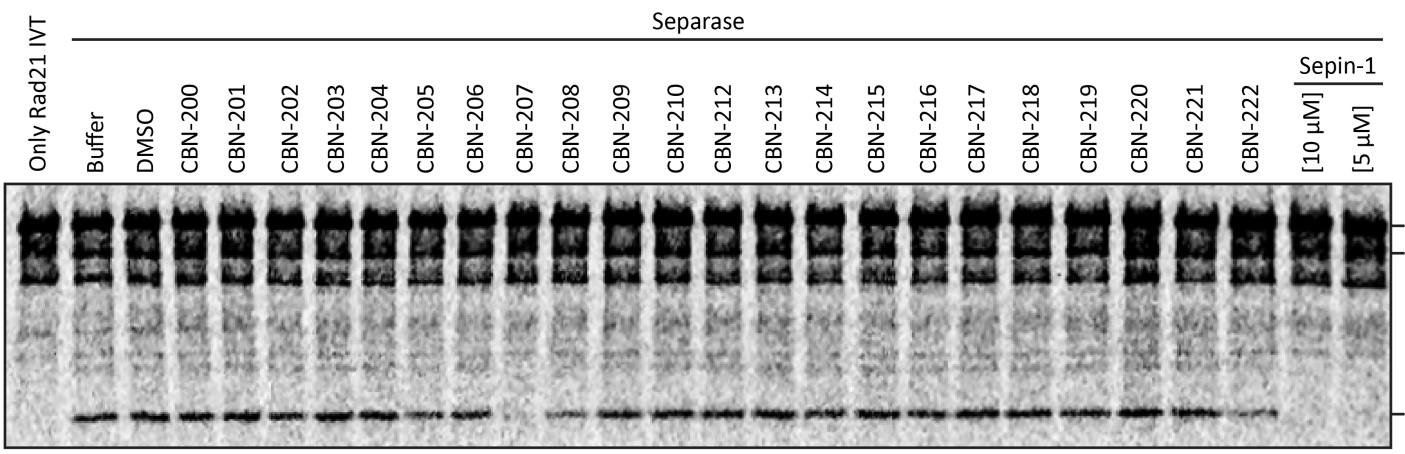

full length Rad21 fragment

fragment 

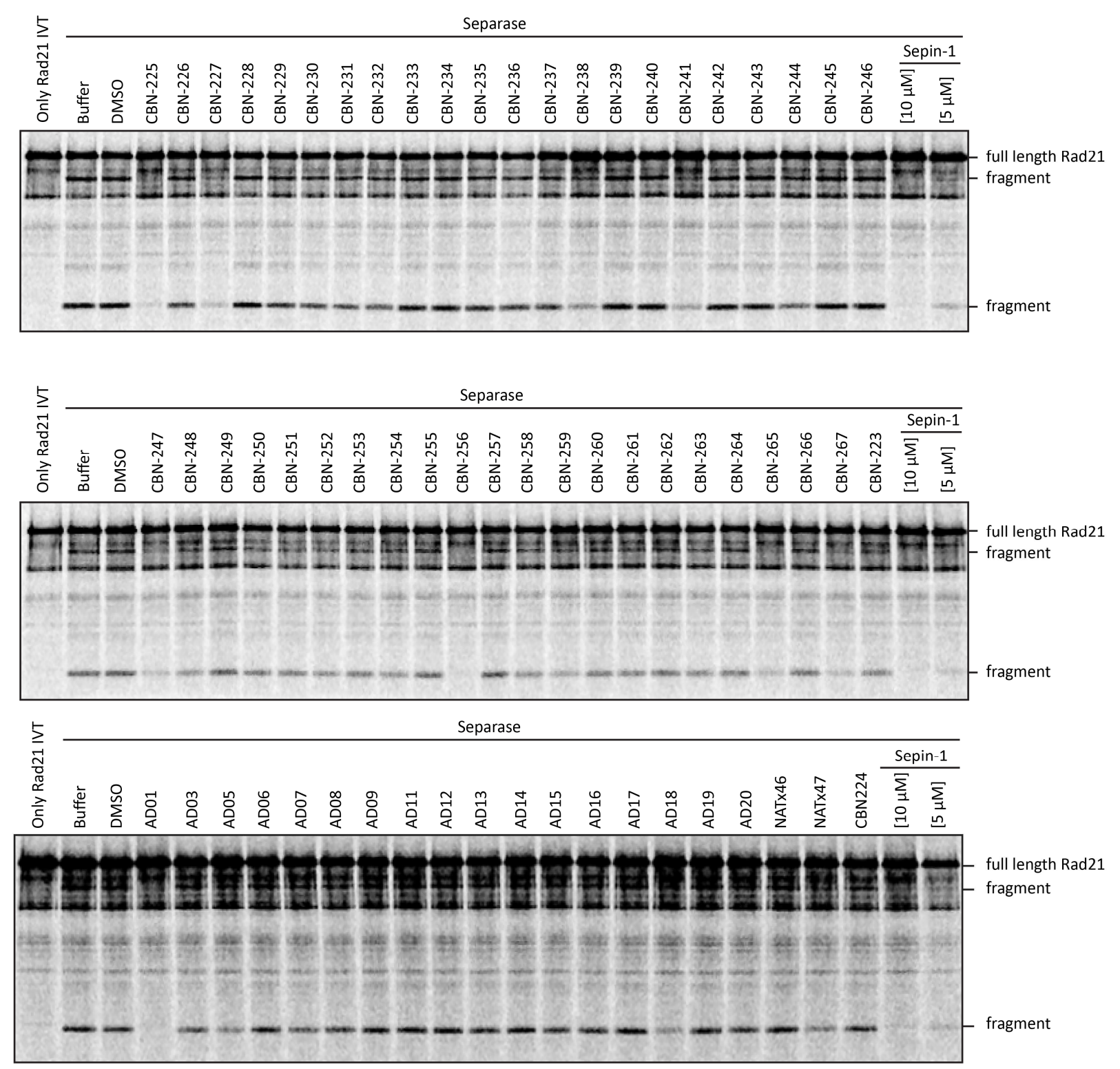

C

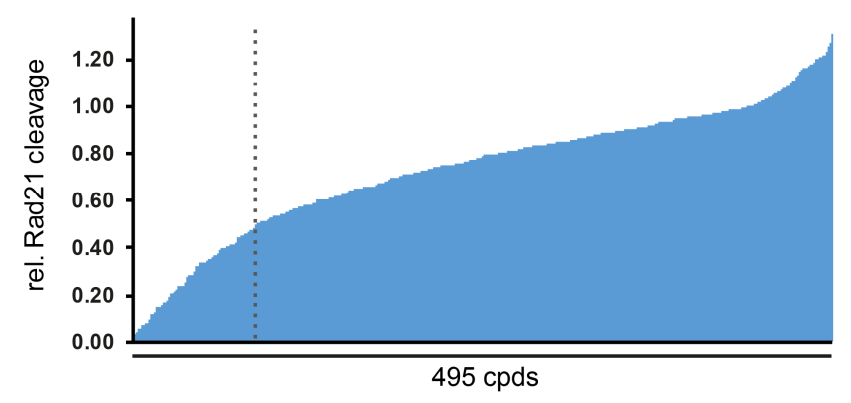

Figure S3: Separase-mediated Rad21 cleavage assay. (A) Validation of the assay. ${ }^{35}$ S-IVT Rad21 was incubated with purified wildtype (WT) or catalytically inactive (C2029A) separase and analyzed by autoradiography. (B) Autoradiograms of 495 compounds, identified in cellbased HTS, all compounds were used at $20 \mu \mathrm{M}$, Sepin-1 was used at $5 \mu \mathrm{M}$ and $10 \mu \mathrm{M}$ and DMSO was used as solvent control, (C) Quantification of lower Rad21 cleavage fragment relative to DMSO control 


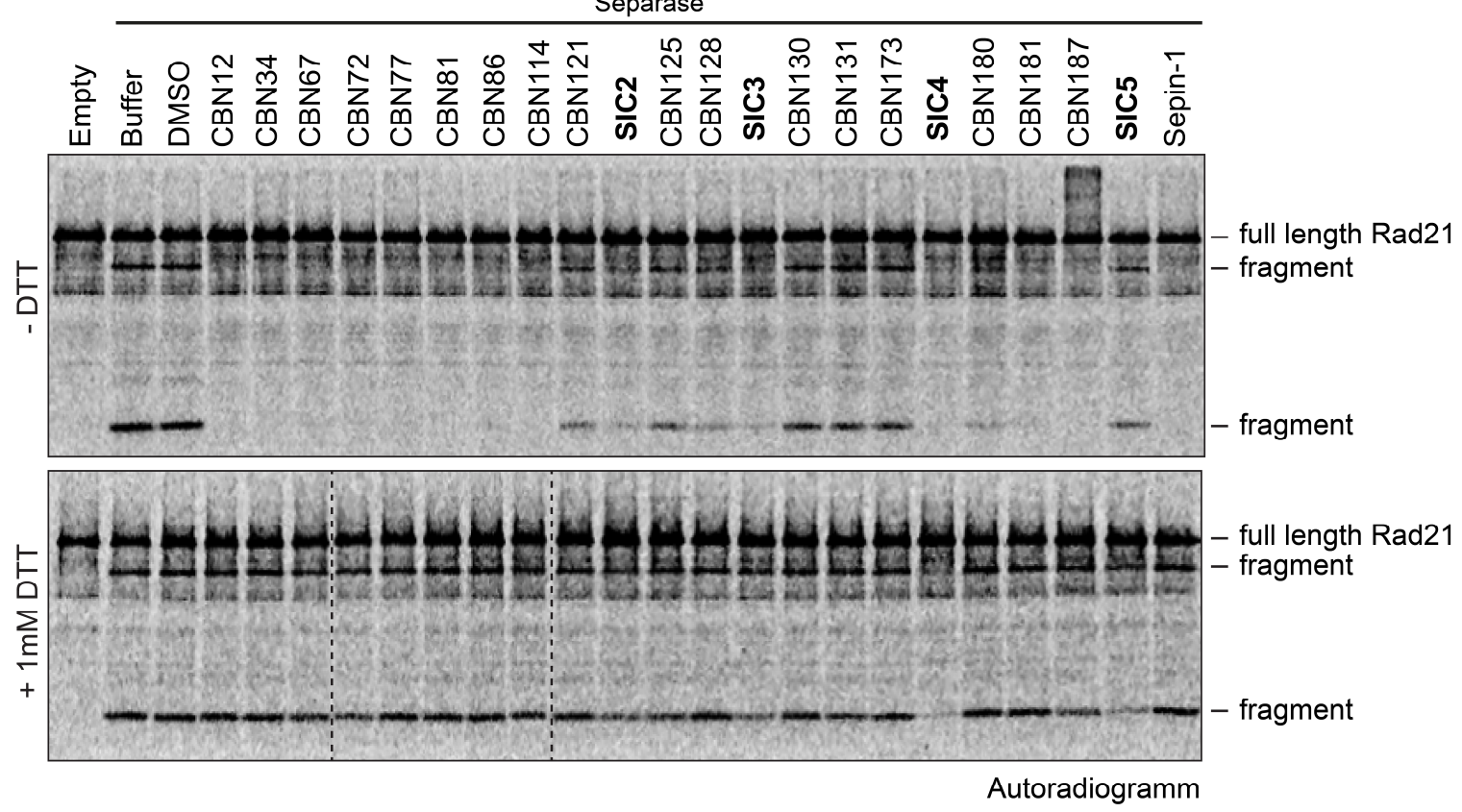

Figure S4: Separase-dependent Rad21 cleavage without (upper panel) or with $1 \mathrm{mM}$ DTT (lower panel). 


\section{Caspase-1 Assay}

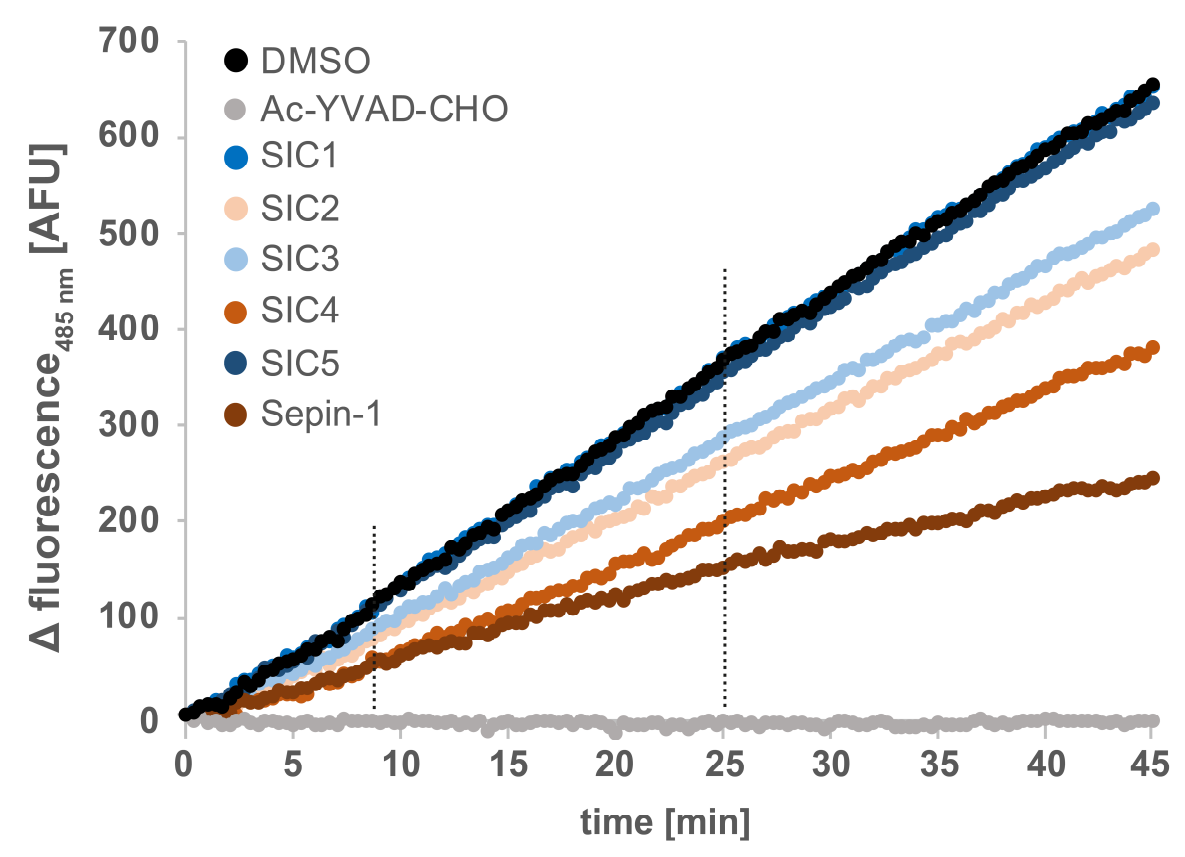

Figure S5: Caspase-1 activity assay. Fluorescence intensity of free AMC (7-Amino-4methylcoumarin) over time with $100 \mu \mathrm{M}$ of SIC1 to SIC5, Sepin-1 and DMSO as solvent control. The Caspase-1 inhibitor Ac-YVAD-CHO was used to confirm that the release of AMC was mediated by Caspase-1. Dashed lines frame the time interval that was used to calculate caspase-1 activity.

A

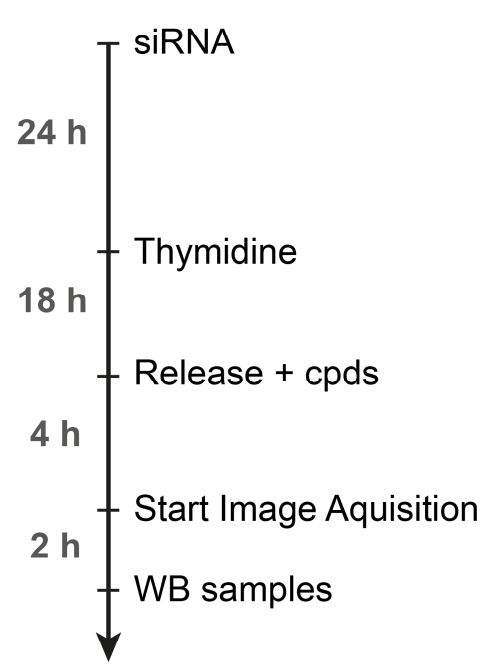

B siCtrl siSeparase

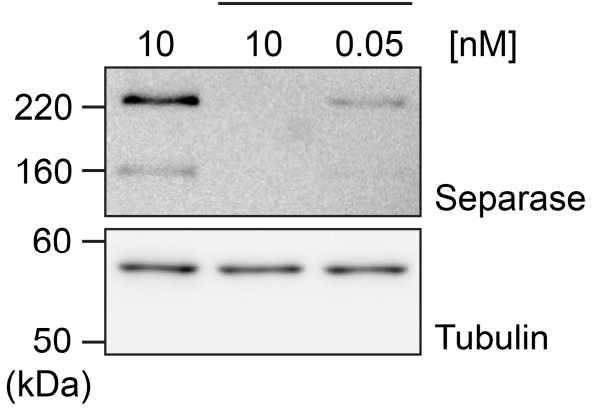

Figure S6: Complete and partial depletion of separase by RNA-interference (RNAi) in HeLacells. (A) Experimental setup of RNAi experiments. (B) Western Blot analysis showing separase levels in HeLa cells transfected with $10 \mathrm{nM}$ or $0.05 \mathrm{nM}$ short-interfering RNAs targeting separase (siSeparase). 


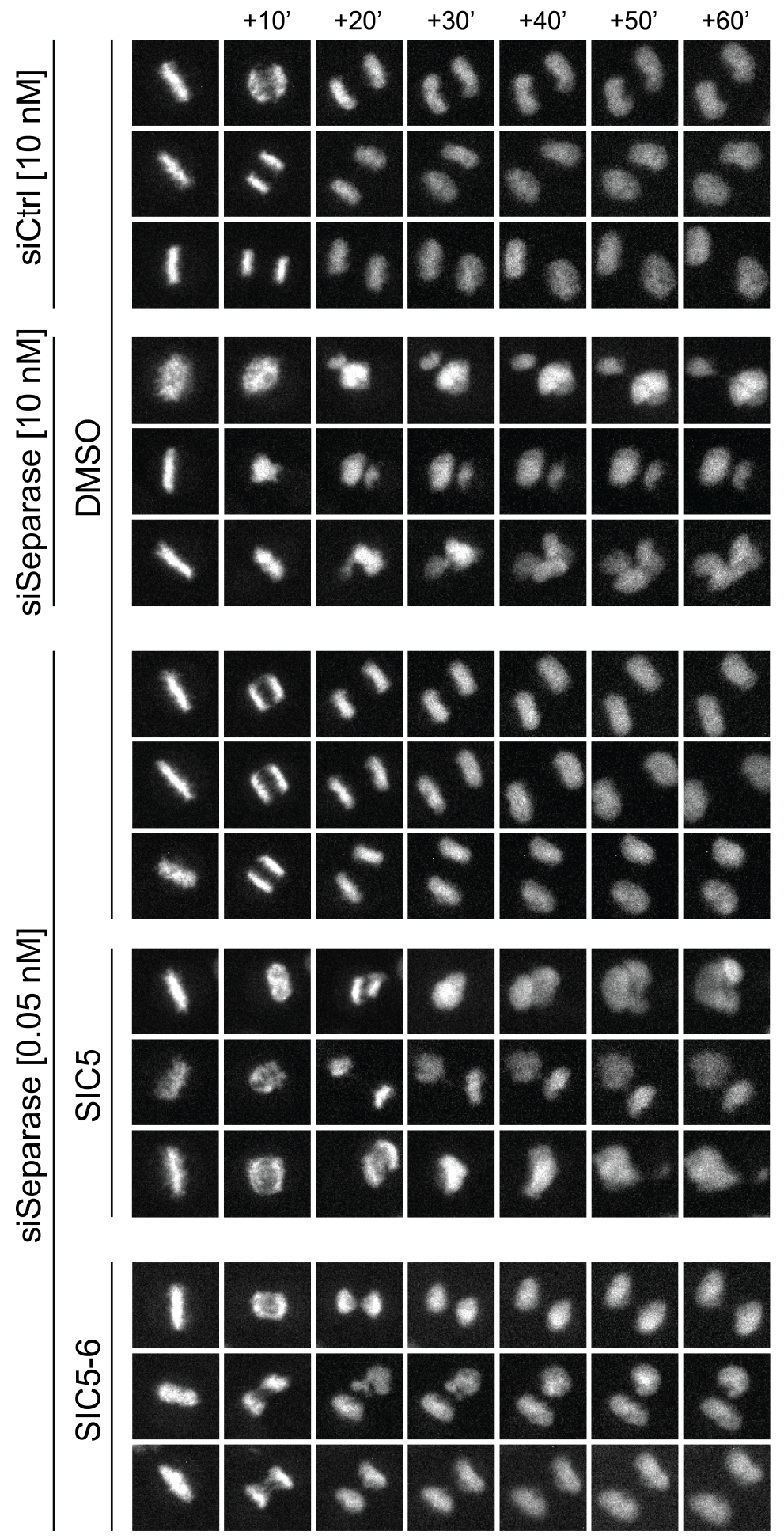

Figure S7: Exemplary images for segregation errors observed in cells completely (10 $\mathrm{nM}$ ) or partially $(0.05 \mathrm{nM})$ depleted of separase (siSeparase) and treated with DMSO or $30 \mu \mathrm{M}$ of the indicated compounds. 


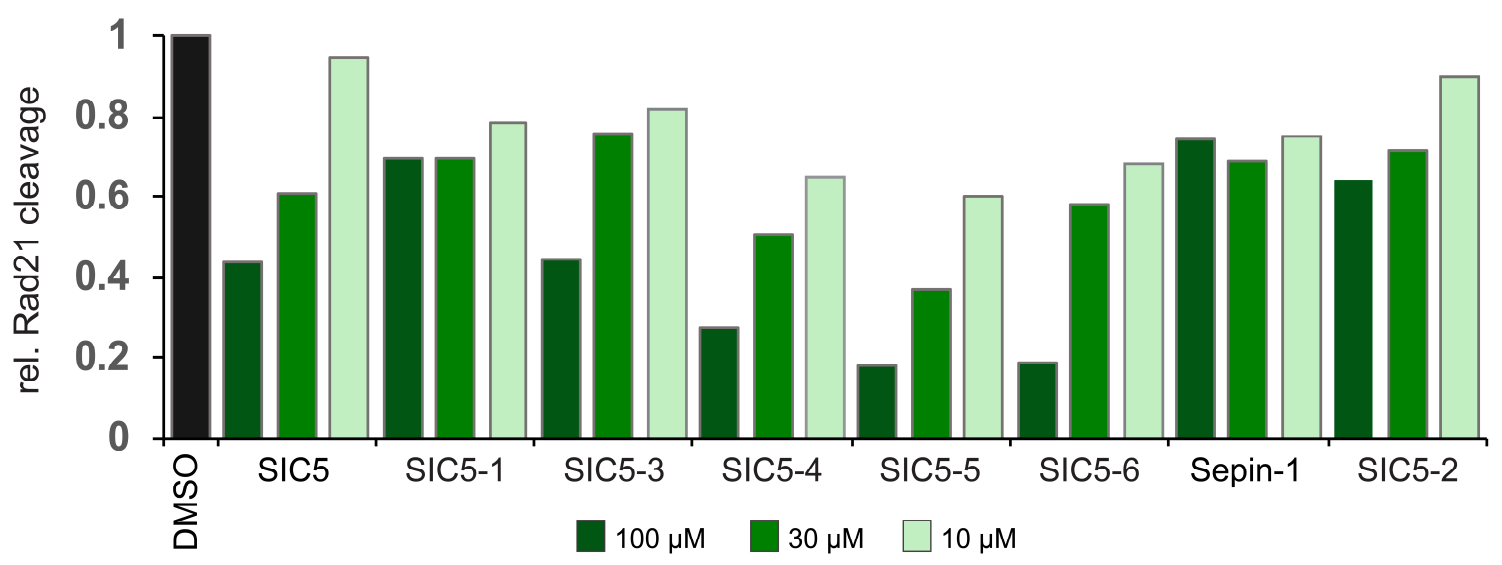

Figure S8: Quantitative analyses of Rad21 cleavage assay in the presence of DMSO, SIC5 derivates or Sepin-1.The signal intensity of the small Rad21 cleavage product was used to quantify separase activity. 


\section{Experimental section}

All materials and reagents were obtained from commercial suppliers and used without further purification.

\subsection{Cell culture}

All cells were cultured in DMEM (Gibco, ThermoFischer Scientific) supplemented with $5 \%$ FCS (Gibco, ThermoFischer Scientific) for high throughput screening or $10 \%$ FCS for all other experiments at $37{ }^{\circ} \mathrm{C}$ and $5 \% \mathrm{CO}_{2}$. HeLa and HEK293-T cell lines stably expressing H2BeGFP-Rad21 128-268-mCherry (separase activity sensor) were generated using PhiC31 integrase for recombination with attB sites. Clones were selected with $0.5 \mathrm{mg} / \mathrm{mL}$ Geniticin (Invivogen). For stable and inducible expression of $\mathrm{Myc}_{6}$-separase ${ }^{\mathrm{PM} 2}$ the corresponding transgene was stably integrated into HEK293-FIpIn-TRex (Invitrogen) already carrying the separase sensor. Clones were selected with $150 \mu \mathrm{g} / \mathrm{ml}$ Hygromycin B (Roth).

Transfection of HEK293-T cells for separase/securin overexpression was done using calcium phosphate.

\subsection{Cell-based high throughput screen}

HEK293-T cells stably expressing the separase activity sensor were incubated in $2 \mathrm{mM}$ thymidine for $20 \mathrm{~h}$ to arrest them in G1/S. After washing two times with PBS, cells were trypsinized and seeded in 384-well plates $(10,000$ cells/well; $50 \mu \mathrm{L})$ in full growth medium supplemented with tetracycline $(0.2 \mu \mathrm{g} / \mu \mathrm{L})$ and taxol $(230 \mathrm{nM})$ to induce separase $\mathrm{PM}^{\mathrm{PM}}$ expression and to arrest them in prometaphase. $4 \mathrm{~h}$ after release from thymidine, screening compounds were transferred to the assay plate with a liquid handling robot (TECAN Freedom Evo workstation) and $30 \mu \mathrm{L}$ medium was added to each well to mix. $24 \mathrm{~h}$ after thymidine release cells were fixed with $4 \%$ PFA in PBS for 12 minutes and washed twice with PBS. Image acquisition was done with a Molecular Devices ImageXpress ${ }^{\text {MICRO }}$ with a Nikon Plan Apo 20x/0.75 DIC N2. Cell segmentation, mitotic classification and hue value measurements 
were done with KNIME. Compounds that did not reduce the mitotic index below $80 \%$ of the control (Taxol) and inhibited the sensor cleavage more than $70 \%$ in mitotic cells were selected.

In total, 51,009 small molecules from commercially available libraries (Maybridge: Hitkit9000 [9000 compounds with unknown target], ChemBioNet 1-3 [27231 compounds with unknown target], ChemDiv [8298 compounds with unknown target] , Analyticon Discovery 1 [1000 natural compounds], Analyticon Discovery 2 [5000 semi-natural compounds] and Biomol ICCB [480 compounds with known target]) were tested.

\subsection{RNA interference}

HeLa cells were transfected with siRNA for $48 \mathrm{~h}$ prior to time lapse experiments using Lipofectamine RNAiMAX Transfection Reagent (Invitrogen, REF13778-075) according to manufacturer's instructions. Dharmacon ON-TARGETplus siRNA against separase (5'-GAUCGUUUCCUAUACAGUA-3') was used at $10 \mathrm{nM}$ or $0.05 \mathrm{nM}$ and non-targeting siRNA (QIAGEN, Cat No. 1027281) was used at $10 \mathrm{nM}$.

\subsection{Preparation of activated separase}

Isolation and activation of separase was performed as described previously ${ }^{1,2}$ with minor modifications. eGFP-TEV ${ }_{4}$-separase and securin were transiently overexpressed in HEK293-T cells. Immunoprecipitation from taxol arrested cell lysate using a recombinant GFP-binding protein $(\mathrm{GBP})^{3}$ coupled to NHS-activated Sepharose 4 Fast flow beads (GE Healtcare) yielded eGFP-TEV-separase/securin complexes. To strip separase from its co-immunoprecipitated inhibitor securin, beads were incubated in anaphase-like xenopus laevis egg extract for 45 min at $20^{\circ} \mathrm{C}$. Elution of activated separase from beads was achieved using recombinant TEV protease.

\subsection{Rad21 cleavage assay}

${ }^{35}$ S-labeled Rad21 was in vitro expressed using (TnT® SP6 High-Yield Wheat Germ Protein Expression System from Promega) in presence of ${ }^{35} \mathrm{~S}$-methionine according to the 
manufacturers' instructions. $8 \mathrm{ng}$ separase in $12 \mu \mathrm{L}$ assay buffer $(10 \mathrm{mM} \mathrm{HEPES} / \mathrm{KOH} \mathrm{pH} 7.7$, $50 \mathrm{mM} \mathrm{NaCl}, 25 \mathrm{mM} \mathrm{NaF}, 10 \mathrm{mM}$ DTT, $1 \mathrm{mM}$ EGTA, 20\% (v/v) glycerol) was incubated with compounds or DMSO for 5 minutes on ice. $\left[{ }^{35} \mathrm{~S}\right]$-methionine-labeled in vitro translated (IVT) Rad21 was used as substrate. $0.01 \mu \mathrm{L} \operatorname{Rad} 21$ IVT in $3 \mu \mathrm{L}$ assay buffer were added to the reaction and mixed. The reaction was incubated at $30{ }^{\circ} \mathrm{C}$ for 30 minutes in a Veriti ${ }^{\mathrm{TM}} 96-$ Well Thermal Cycler. Addition of Lämmli buffer stopped the reaction and samples were cooked at $95^{\circ} \mathrm{C}$ for $5 \mathrm{~min}$. Cleaved Rad21 was separated by SDS-PAGE and visualized by autoradiography. The smaller cleavage fragment was quantified using ImageJ.

\subsection{Caspase-1 assay}

To measure Caspase-1 activity the Caspase-1 assay kit for drug discovery (Enzo BML-AK7010001) was used. The assay was scaled down to $50 \mu \mathrm{L}$ total reaction volume (instead of $100 \mu \mathrm{L})$. 


\section{Synthesis of SIC5 and derivates}

1-((4-fluorophenyl)sulfonyl)piperidin-4-one (2a),

1-((4-iodophenyl)sulfonyl)piperidin-4-one (2b)

and 1-(4-fluorobenzoyl)piperidin-4-one (2c)<smiles>O=S(=O)(Cl)c1ccc(F)cc1</smiles>

1 a<smiles>O=S(=O)(Cl)c1ccc(I)cc1</smiles>

$1 \mathrm{~b}$<smiles>O=C(Cl)c1ccc(F)cc1</smiles>

$1 c$<smiles>O=C1CCN(S(=O)(=O)c2ccc(F)cc2)CC1</smiles>

$2 \mathbf{a}$<smiles>O=C1CCN(S(=O)(=O)c2ccc(I)cc2)CC1</smiles>

$2 \mathbf{b}$

2c

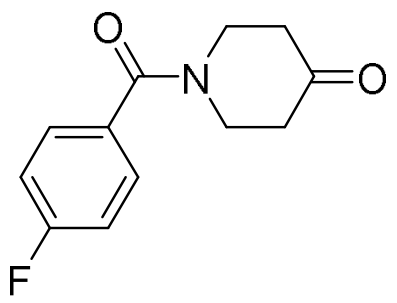

\section{Procedure}

Under nitrogen atmosphere, 1.0 eq. of piperidone was dissolved in dry DCM (1 mL per $20 \mathrm{mg}$ piperidone) and 1.1 eq. of the respective sulfonyl or acyl chloride 1a-c were added. After the addition of 3.0 eq. triethylamine, the mixture was refluxed for $2 \mathrm{~h}$. Upon reaction completion, the solvent was evaporated and the residue was purified via MPLC (linear gradient, MeCN in $\mathrm{MQ}$ from $5 \%$ to $100 \%$ ). Fractions containing the product $\mathbf{2 a - c}$ were pooled, concentrated and used in the next reaction.

Compound 2a: $141 \mathrm{mg}, 81 \%$.

${ }^{1} \mathrm{H} \mathrm{NMR}\left(\mathrm{CDCl}_{3}, 400 \mathrm{MHz}\right) \delta[\mathrm{ppm}]=7.88-7.80(\mathrm{~m}, 2 \mathrm{H}), 7.30-7.22(\mathrm{~m}, 2 \mathrm{H}), 3.42(\mathrm{t}, J=6.2$ $\mathrm{Hz}, 4 \mathrm{H}), 2.58(\mathrm{t}, J=6.2 \mathrm{~Hz}, 4 \mathrm{H}) .{ }^{13} \mathrm{C}$ NMR $\left(\mathrm{CDCl}_{3}, 101 \mathrm{MHz}\right) \delta[\mathrm{ppm}]=205.36,166.80,164.26$, $132.70,130.40,130.30,116.89,116.67,45.96,40.77 .{ }^{19} \mathbf{F ~ N M R ~}\left(\mathrm{CDCl}_{3}, 376 \mathrm{MHz}\right) \delta[\mathrm{ppm}]=$ $-104.11(\mathrm{~s}, 1 \mathrm{~F})$.

Compound 2b: $124 \mathrm{mg}, 52 \%$.

${ }^{1} \mathrm{H} \mathrm{NMR}\left(\mathrm{CDCl}_{3}, 400 \mathrm{MHz}\right) \delta[\mathrm{ppm}]=7.99-7.83(\mathrm{~m}, 2 \mathrm{H}), 7.55-7.43(\mathrm{~m}, 2 \mathrm{H}), 3.40(\mathrm{t}, J=6.2$ $\mathrm{Hz}, 4 \mathrm{H}), 2.54(\mathrm{t}, J=6.2 \mathrm{~Hz}, 4 \mathrm{H}) .{ }^{13} \mathrm{C}$ NMR $\left(\mathrm{CDCl}_{3}, 101 \mathrm{MHz}\right) \delta[\mathrm{ppm}]=205.07,138.63,136.26$, $128.79,100.78,45.80,40.65$. 
Compound 2c: $220 \mathrm{mg}, 76 \%$.

${ }^{1} \mathrm{H} \mathrm{NMR}\left(\mathrm{CDCl}_{3}, 400 \mathrm{MHz}\right) \delta[\mathrm{ppm}]=7.74-7.50(\mathrm{~m}, 2 \mathrm{H}), 7.37-6.98(\mathrm{~m}, 2 \mathrm{H}), 2.48(\mathrm{t}, J=6.3$ $\mathrm{Hz}, 5 \mathrm{H}) .{ }^{13} \mathrm{C}$ NMR $\left(\mathrm{CDCl}_{3}, 101 \mathrm{MHz}\right) \delta[\mathrm{ppm}]=206.70,169.88,165.47,163.01,133.51$, $133.48,130.55,130.46,116.23,116.01,41.47 .{ }^{19} \mathrm{~F} \mathrm{NMR}\left(\mathrm{CDCl}_{3}, 376 \mathbf{~ M H z}\right) \delta[\mathrm{ppm}]=-113.51$ $(\mathrm{s}, 1 \mathrm{~F})$.

3,3'-(1-((4-fluorophenyl)sulfonyl)piperidine-4,4-diyl)bis(1H-indole) (3a, SIC5), 3,3'-(1-((4-iodophenyl)sulfonyl)piperidine-4,4-diyl)bis(1H-indole) (3b, SIC5-6) and (4,4-di(1H-indol-3-yl)piperidin-1-yl)(4-fluorophenyl)methanone (3c, SIC5-3)<smiles>O=C1CCN(S(=O)(=O)c2ccc(F)cc2)CC1</smiles><smiles>O=S(=O)(c1ccc(F)cc1)N1CCC(c2c[nH]c3ccccc23)(c2c[nH]c3ccccc23)CC1</smiles>

$2 a$<smiles>O=C1CCN(S(=O)(=O)c2ccc(I)cc2)CC1</smiles>

2b

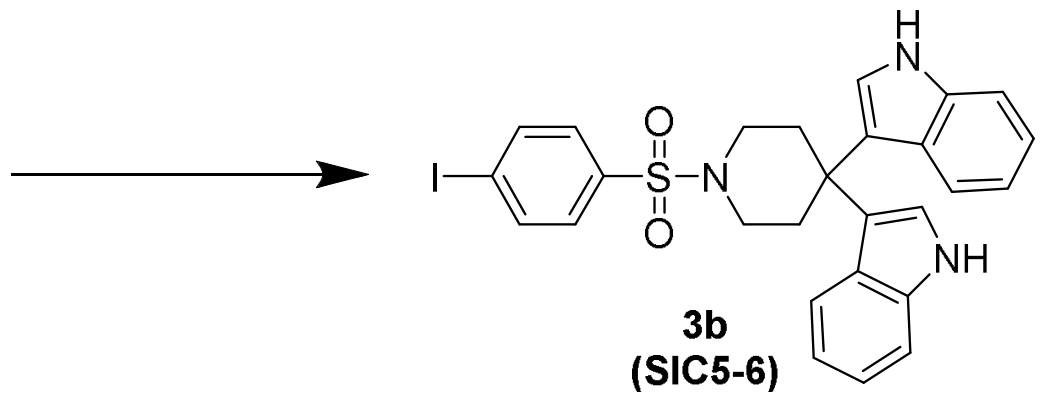

2c<smiles>O=C1CCN(C(=O)c2ccc(F)cc2)CC1</smiles><smiles>O=C(c1ccc(F)cc1)N1CCC(c2c[nH]c3ccccc23)(c2c[nH]c3ccccc23)CC1</smiles>

\section{Procedure}

1.0 eq. of compound $2 \mathrm{a}-\mathrm{c}, 2.0$ eq. of indole and 0.1 eq. of trityl chloride were dissolved in 1:1 $\mathrm{MeCN} / \mathrm{AcOH}$ ( $1 \mathrm{~mL}$ per $30 \mathrm{mg}$ indole). The reaction was stirred at RT for 2 days. The mixture was evaporated and the residue was purified via MPLC (linear gradient, MeCN in MQ from $40 \%$ to $100 \%$ ) to give compound 3 a-c. 
Compound 3a (SIC5): $83 \mathrm{mg}, 27 \%$.

${ }^{1} \mathrm{H}$ NMR (MeCN-d $\left.3,400 \mathrm{MHz}\right) \delta[p p m] 9.09(\mathrm{~s}, 2 \mathrm{H}), 7.82-7.71(\mathrm{~m}, 2 \mathrm{H}), 7.31-7.17(\mathrm{~m}, 8 \mathrm{H})$, 6.94 (ddd, $J=8.2,6.9,1.2 \mathrm{~Hz}, 2 \mathrm{H}$ ), 6.73 (ddd, $J=8.1,7.0,1.1 \mathrm{~Hz}, 2 \mathrm{H}$ ), 3.17 (t, $J=5.5,4 \mathrm{H}$ ), $2.63(\mathrm{t}, J=5.5,4 \mathrm{H}) .{ }^{13} \mathrm{C}$ NMR $\left(\mathbf{M e C N}_{-} \boldsymbol{d}_{3}, 101 \mathrm{MHz}\right) \delta[\mathrm{ppm}] 167.33,164.83,138.18,133.67$, $131.55,131.45,126.75,123.13,122.11,121.39,121.27,119.23,118.32,117.34,117.11$, 112.38, 44.31, 37.58, 36.23. ${ }^{19} \mathrm{~F} \mathrm{NMR} \mathrm{(MeCN-d_{3 } , 3 7 6 ~ M H z )} \delta[p p m]=-108.58(\mathrm{~s}, 1 \mathrm{~F})$. HR-MS (ESI, m/z): calc. for $\mathrm{C}_{27} \mathrm{H}_{24} \mathrm{FN}_{3} \mathrm{O}_{2} \mathrm{~S}$ ([M-H] $\left.]^{-}\right) 472.1490$, found 472.1503

Compound 3b (SIC5-6): 156 mg, 21\%.

${ }^{1} \mathrm{H}$ NMR $\left(\mathrm{MeCN}_{-} \boldsymbol{d}_{3}, 400 \mathrm{MHz}\right) \delta[\mathrm{ppm}]=9.10(\mathrm{~s}, 2 \mathrm{H}), 7.95-7.87(\mathrm{~m}, 2 \mathrm{H}), 7.50-7.42(\mathrm{~m}, 2 \mathrm{H})$, $7.31-7.24(\mathrm{~m}, 2 \mathrm{H}), 7.25-7.16(\mathrm{~m}, 4 \mathrm{H}), 6.94$ (ddd, $J=8.2,6.9,1.1 \mathrm{~Hz}, 2 \mathrm{H}), 6.73$ (ddd, $J=$ 8.3, 6.9, 1.0 Hz, 2H), $3.18(\mathrm{t}, J=5.6 \mathrm{~Hz}, 4 \mathrm{H}), 2.63(\mathrm{t}, J=5.6 \mathrm{~Hz}, 4 \mathrm{H}) .{ }^{13} \mathrm{C} \mathrm{NMR}\left(\mathrm{MeCN}^{-d_{3}, 101}\right.$ MHz) $\delta[\mathrm{ppm}]=139.40,138.18,137.34,130.07,126.74,123.15,122.11,121.36,121.26$, $119.25,118.32,112.38,100.66,44.29,37.61,36.22,1.32$. HR-MS (ESI, $\mathbf{m} / \mathbf{z}): \quad$ calc. for $\mathrm{C}_{27} \mathrm{H}_{24} \mathrm{IN}_{3} \mathrm{O}_{2} \mathrm{~S}\left([\mathrm{M}-\mathrm{H}]^{-}\right)$580.0550, found 580.0628 .

Compound 3c (SIC5-3): $104 \mathrm{mg}, 26 \%$.

${ }^{1} \mathrm{H}$ NMR $\left(\mathrm{MeCN}_{-} \mathrm{d}_{3}, 400 \mathrm{MHz}\right) \delta[\mathrm{ppm}]=9.21(\mathrm{~s}, 2 \mathrm{H}), 7.50-7.41(\mathrm{~m}, 2 \mathrm{H}), 7.39(\mathrm{~d}, J=2.6 \mathrm{~Hz}$, $2 \mathrm{H}$ ), $7.34-7.25(\mathrm{~m}, 4 \mathrm{H}), 7.19-7.09(\mathrm{~m}, 2 \mathrm{H}), 6.95$ (ddd, $J=8.2,7.0,1.2 \mathrm{~Hz}, 2 \mathrm{H}), 6.74$ (ddd, $J=8.1,7.0,1.1 \mathrm{~Hz}, 2 \mathrm{H}), 3.82(\mathrm{~s}, 2 \mathrm{H}), 3.53(\mathrm{~s}, 2 \mathrm{H}), 2.63(\mathrm{~s}, 2 \mathrm{H}), 2.54(\mathrm{~s}, 2 \mathrm{H}) .{ }^{13} \mathrm{C}$ NMR (MeCN$\left.\boldsymbol{d}_{3}, 101 \mathrm{MHz}\right) \delta[\mathrm{ppm}]=138.26,130.36,130.27,126.95,123.18,122.07,121.92,121.38$,

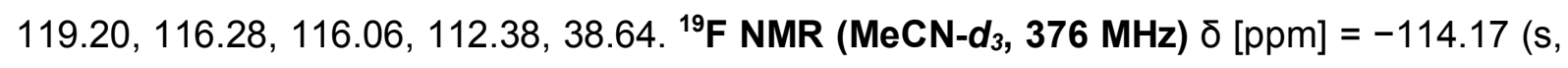
1F). HR-MS (ESI, m/z): calc. for $\mathrm{C}_{28} \mathrm{H}_{24} \mathrm{FN}{ }_{3} \mathrm{O}\left([\mathrm{M}-\mathrm{H}]^{-}\right)$436.1820, found 436.1764.

3-(1-((4-fluorophenyl)sulfonyl)-1,2,3,6-tetrahydropyridin-4-yl)-1H-indole (5, SIC52)
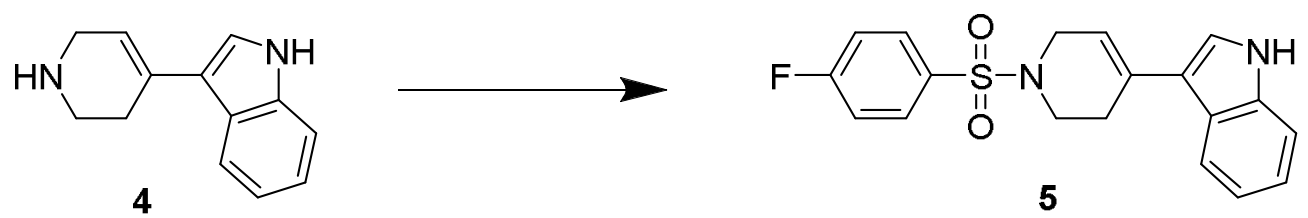

\section{Procedure}

$330 \mathrm{mg}$ (2.82 mmol, 1.0 eq.) indole were added to a solution of $1.20 \mathrm{~g}$ (27.4 mmol, 7.5 eq.) $\mathrm{KOH}$ in $20 \mathrm{~mL} \mathrm{MeOH}$. Afterwards, $1.10 \mathrm{~g}$ (7.16 mmol, 2.5 eq.) 4-piperidone were suspended 
and the mixture was refluxed for $17 \mathrm{~h}$. The solvent was evaporated and the residue was purified via MPLC (linear gradient, MeCN in MQ from $20 \%$ to $100 \%$ ) to give compound 4.

Under nitrogen atmosphere, $135 \mathrm{mg}(0.681 \mathrm{mmol}, 1.0$ eq.) of 4 were dissolved in $10 \mathrm{~mL}$ dry DCM and $147 \mathrm{mg}(0.749 \mathrm{mmol}, 1.1$ eq.) 4-fluorobenzenesulfonyl chloride were added. After the addition of $290 \mu \mathrm{L}$ triethylamine $(2.09 \mathrm{mmol}, 3.1 \mathrm{eq}$.), the mixture was refluxed for $2 \mathrm{~h}$. Upon reaction completion, the solvent was evaporated and the residue was purified via MPLC (linear gradient, MeCN in MQ from 40\% to 100\%) to give compound 5 .

Compound 4: $147 \mathrm{mg}, 26 \%$.

${ }^{1} \mathrm{H}$ NMR (DMF-d $\left.\boldsymbol{d}_{7}, 400 \mathrm{MHz}\right) \delta[\mathrm{ppm}]=7.81(\mathrm{dt}, J=7.9,1.0 \mathrm{~Hz}, 1 \mathrm{H}), 7.35(\mathrm{dt}, J=8.1,1.0 \mathrm{~Hz}$, $1 \mathrm{H}), 7.22(\mathrm{~s}, 1 \mathrm{H}), 7.16-6.97(\mathrm{~m}, 2 \mathrm{H}), 6.18(\mathrm{tt}, J=3.4,1.6 \mathrm{~Hz}, 1 \mathrm{H}), 3.47(\mathrm{q}, J=2.7 \mathrm{~Hz}, 2 \mathrm{H}$ ), $3.03(\mathrm{t}, J=5.8 \mathrm{~Hz}, 2 \mathrm{H}), 2.60-2.39(\mathrm{~m}, 2 \mathrm{H}) .{ }^{13} \mathrm{C}$ NMR (DMF-d, $\left.101 \mathrm{MHz}\right) \delta[\mathrm{ppm}]=138.74$, $131.94,126.45,122.92,122.53,121.23,120.37,119.77,118.32,112.49$, 45.64, 43.97, 29.03.

Compound 5 (SIC5-2): 108 mg, 44\%.

${ }^{1} \mathrm{H}$ NMR (DMF-d $\left.{ }_{7}, 400 \mathrm{MHz}\right) \delta[\mathrm{ppm}]=11.23(\mathrm{~s}, 1 \mathrm{H}), 8.03-7.98(\mathrm{~m}, 2 \mathrm{H}), 7.89(\mathrm{~d}, J=7.9 \mathrm{~Hz}$, $1 \mathrm{H}), 7.56-7.47(\mathrm{~m}, 4 \mathrm{H}), 7.19-7.08(\mathrm{~m}, 2 \mathrm{H}), 6.21(\mathrm{td}, J=3.6,1.5 \mathrm{~Hz}, 1 \mathrm{H}), 3.84(\mathrm{q}, J=2.7$ $\mathrm{Hz}, 2 \mathrm{H}$ ), 3.36 (t, $J=5.8 \mathrm{~Hz}, 2 \mathrm{H}$ ), 2.71 (tq, $J=6.2,2.1 \mathrm{~Hz}, 2 \mathrm{H}$ ). ${ }^{13} \mathrm{C}$ NMR (DMF-d, $101 \mathrm{MHz}$ ) $\delta[\mathrm{ppm}]=166.65,164.15,137.84,133.08,133.05,131.12,131.02,130.58,125.27,123.60$, $121.81,120.35,119.80,116.92,116.69,116.08,115.09,112.14,45.54,43.59,28.25 .{ }^{19} \mathrm{~F} \mathrm{NMR}$ $\left(\right.$ DMF- $d_{7}, 376$ MHz) $\delta[p p m]=-107.23$ (s, 1F). HR-MS (ESI, m/z): calc. for $\mathrm{C}_{19} \mathrm{H}_{17} \mathrm{FN}_{2} \mathrm{O}_{2} \mathrm{~S}$ ([M-H] $\left.]^{-}\right)$355.0911, found 355.0928.

\section{3-(1-((4-fluorophenyl)sulfonyl)piperidin-4-yl)-1H-indole (5, SIC5-1)}
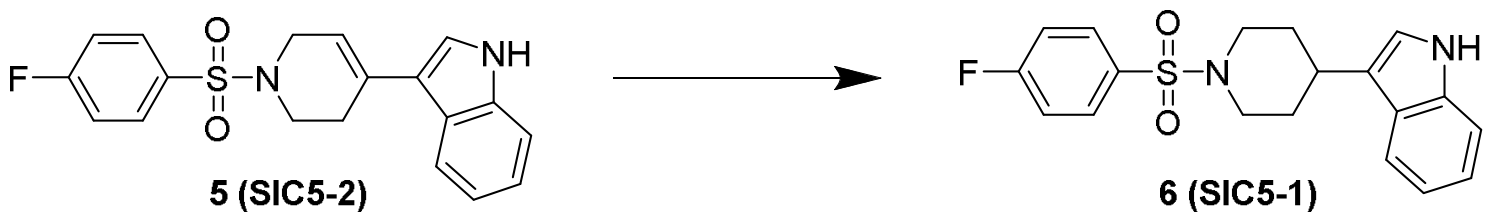

\section{Procedure}

$100 \mathrm{mg}(0.281 \mathrm{mmol}, 1.0$ eq. $)$ of compound 5 was dissolved in $1: 1 \mathrm{MeOH} / \mathrm{DCM}(10 \mathrm{~mL})$ and $22 \mathrm{mg} \mathrm{Pd} / \mathrm{C}$ (10 wt\%) was added. After the addition of $330 \mu \mathrm{L}$ aqueous $\mathrm{HCl}(37 \%)$, the atmosphere was changed to $\mathrm{H}_{2}$ gas. The mixture was stirred at RT for $22 \mathrm{~h}$. The suspension was filtrated and the filtrate was evaporated. The residue was purified via MPLC (linear gradient, MeCN in MQ from $40 \%$ to $100 \%$ ) to give compound 6 . 
Compound 6 (SIC5-1): $70 \mathrm{mg}, 70 \%$.

${ }^{1} \mathbf{H}$ NMR (MeOD-d 4 , 400 MHz) $\delta[p p m]=7.94-7.90(\mathrm{~m}, 2 \mathrm{H}), 7.53-7.47(\mathrm{~m}, 1 \mathrm{H}), 7.45-$ $7.38(\mathrm{~m}, 2 \mathrm{H}), 7.36-7.31(\mathrm{~m}, 1 \mathrm{H}), 7.13-7.04(\mathrm{~m}, 1 \mathrm{H}), 7.04-6.93(\mathrm{~m}, 2 \mathrm{H}), 4.01-3.82(\mathrm{~m}$, $2 \mathrm{H}), 2.93-2.76(\mathrm{~m}, 1 \mathrm{H}), 2.56(\mathrm{td}, J=12.0,2.5 \mathrm{~Hz}, 2 \mathrm{H}), 2.13(\mathrm{~d}, J=13.3 \mathrm{~Hz}, 2 \mathrm{H}), 1.85$ (qd, $J$ $=12.5,4.0 \mathrm{~Hz}, 2 \mathrm{H}) .{ }^{13} \mathrm{C}$ NMR (MeOD-d $\left.4,151 \mathrm{MHz}\right) \delta[\mathrm{ppm}] 167.56,165.88,138.24,134.09$, $134.07,131.82,131.75,127.65,122.30,121.18,120.17,119.49,119.42,117.44,117.29$, 112.29, 48.13, 34.14, 33.49. ${ }^{19} \mathrm{~F}$ NMR (MeOD-d 4376 MHz) $\delta[p p m]=-108.65$ (s, 1F). HR-MS (ESI, m/z): calc. for $\mathrm{C}_{19} \mathrm{H}_{19} \mathrm{FN}_{2} \mathrm{O}_{2} \mathrm{~S}\left([\mathrm{M}-\mathrm{H}]^{-}\right)$357.1068, found 357.1085. 


\section{Characterization of SIC1-4 \& Sepin-1}

SIC1-4 were purchased from MOLPORT and identified by ${ }^{1} \mathrm{H}$ - and ${ }^{13} \mathrm{C}$ NMR as well as by HR-MS (ESI).

\section{SIC1}<smiles>O=C(Nc1cccs1)Nc1cc(C(F)(F)F)ccc1N1CCCC1</smiles>

${ }^{1} \mathrm{H}$ NMR (DMSO-d, $\left.400 \mathrm{MHz}\right) \delta[\mathrm{ppm}]=10.09(\mathrm{~s}, 1 \mathrm{H}), 8.06(\mathrm{~s}, 1 \mathrm{H}), 7.94(\mathrm{~d}, J=2.3 \mathrm{~Hz}, 1 \mathrm{H})$, $7.31(\mathrm{dd}, J=8.5,2.2 \mathrm{~Hz}, 1 \mathrm{H}), 7.08(\mathrm{~d}, J=8.5 \mathrm{~Hz}, 1 \mathrm{H}), 6.87$ (dd, $J=5.5,1.4 \mathrm{~Hz}, 1 \mathrm{H}), 6.84-$ $6.75(\mathrm{~m}, 1 \mathrm{H}), 6.54(\mathrm{dd}, J=3.7,1.4 \mathrm{~Hz}, 1 \mathrm{H}), 3.26-3.14(\mathrm{~m}, 4 \mathrm{H}), 1.98-1.84(\mathrm{~m}, 4 \mathrm{H}) .{ }^{13} \mathrm{C}$ NMR (DMSO-d $6101 \mathrm{MHz}) \delta[\mathrm{ppm}]=152.06,145.62,141.06,128.74,126.07,124.13,123.38$, 120.96, 120.93, 120.30, 120.26, 120.08, 119.76, 116.92, 115.85, 109.13, 50.31, 39.53, 24.54. ${ }^{19} \mathrm{~F}$ NMR (DMSO-d, $\left.376 \mathrm{MHz}\right) \delta[\mathrm{ppm}]=-60.37$ (s, 1F). HR-MS (ESI, m/z): calc. for $\mathrm{C}_{16} \mathrm{H}_{16} \mathrm{~F}_{3} \mathrm{~N}_{3} \mathrm{OS}\left([\mathrm{M}+\mathrm{H}]^{+}\right)$356.1039, found 356.1022.

\section{$\underline{\mathrm{SIC} 2}$}<smiles>COc1ccc(C=C2CSC/C(=C\c3ccc(OC)cc3)C2=O)cc1</smiles>

${ }^{1} \mathrm{H}$ NMR $\left(\mathrm{CDCl}_{3}, 400 \mathrm{MHz}\right) \delta[\mathrm{ppm}]=7.75(\mathrm{~s}, 2 \mathrm{H}), 7.42-7.33(\mathrm{~m}, 4 \mathrm{H}), 6.99-6.87(\mathrm{~m}, 4 \mathrm{H})$, $3.93(\mathrm{~s}, 4 \mathrm{H}), 3.85(\mathrm{~s}, 6 \mathrm{H}) .{ }^{13} \mathrm{C}$ NMR $\left(\mathrm{CDCl}_{3}, 101 \mathrm{MHz}\right) \delta[\mathrm{ppm}]=189.03,160.38,136.81$, 132.27, 132.14, 127.96, 114.27, 55.52, 30.34. HR-MS (ESI, m/z): calc. for $\mathrm{C}_{21} \mathrm{H}_{20} \mathrm{O}_{3} \mathrm{~S}\left([\mathrm{M}+\mathrm{H}]^{+}\right)$ 353.1206 , found 353.1335 . 
<smiles>O=C1C2C3CC(C2C(=O)N1c1ccc(Cl)cc1)C1C(c2ccc(O)cc2)c2sc(=O)[nH]c2SC31</smiles>

${ }^{1} \mathrm{H}$ NMR (DMSO-d $\left.6,400 \mathrm{MHz}\right) \delta[\mathrm{ppm}]=11.46(\mathrm{~s}, 1 \mathrm{H}), 9.43(\mathrm{~s}, 1 \mathrm{H}), 7.71-7.45(\mathrm{~m}, 2 \mathrm{H}), 7.45$ - $7.25(\mathrm{~m}, 2 \mathrm{H}), 7.21-7.02(\mathrm{~m}, 2 \mathrm{H}), 6.81-6.59(\mathrm{~m}, 2 \mathrm{H}), 3.53-3.41(\mathrm{~m}, 3 \mathrm{H}), 3.35-3.27(\mathrm{~m}$, $1 \mathrm{H}), 2.72(\mathrm{~d}, J=5.5 \mathrm{~Hz}, 1 \mathrm{H}), 2.47(\mathrm{~s}, 1 \mathrm{H}), 2.42(\mathrm{~d}, J=5.3 \mathrm{~Hz}, 1 \mathrm{H}), 2.23(\mathrm{t}, J=9.1 \mathrm{~Hz}, 1 \mathrm{H})$, $1.70(\mathrm{~d}, J=10.5 \mathrm{~Hz}, 1 \mathrm{H}) .{ }^{13} \mathrm{C}$ NMR (DMSO-d $\left.6,101 \mathrm{MHz}\right) \delta[\mathrm{ppm}]=175.79,175.69,170.77$, 156.71, 132.88, 130.86, 130.40, 129.52, 129.20, 128.90, 119.95, 115.39, 115.04, 52.14, 48.31, 48.27, 46.93, 45.33, 44.70, 44.22, 38.13. HR-MS (ESI, m/z): calc. for $\mathrm{C}_{25} \mathrm{H}_{19} \mathrm{CIN}_{2} \mathrm{O}_{4} \mathrm{~S}_{2}\left([\mathrm{M}+\mathrm{H}]^{+}\right)$ 511.0548 , found 511.0524 .

\section{SIC4}<smiles>Cc1cccc(CN2C(=O)/C(=C\c3ccc(C(=O)N4CCN(C(=O)c5ccco5)CC4)cc3)Sc3ccccc32)c1</smiles>

${ }^{1} \mathrm{H}$ NMR (DMSO- $\left.\mathrm{d}_{6}, 400 \mathrm{MHz}\right) \delta[\mathrm{ppm}]=7.93(\mathrm{~s}, 1 \mathrm{H}), 7.85(\mathrm{~s}, 1 \mathrm{H}), 7.82-7.73(\mathrm{~m}, 2 \mathrm{H}), 7.65$ - $7.52(\mathrm{~m}, 2 \mathrm{H}), 7.46-7.32(\mathrm{~m}, 1 \mathrm{H}), 7.27-7.14(\mathrm{~m}, 2 \mathrm{H}), 7.14-6.92(\mathrm{~m}, 6 \mathrm{H}), 6.64$ (dd, $J=$ 3.4, $1.8 \mathrm{~Hz}, 1 \mathrm{H}$ ), $3.61(\mathrm{~d}, J=101.4 \mathrm{~Hz}, 10 \mathrm{H}), 2.28(\mathrm{~s}, 3 \mathrm{H}) .{ }^{13} \mathrm{C}$ NMR (DMSO-d, $\left.101 \mathrm{MHz}\right) \delta$ $[\mathrm{ppm}]=168.59,160.43,158.47,146.74,144.89,137.84,136.51,135.89,135.82,135.34$, 133.20, 130.04, 128.58, 127.70, 127.47, 127.33, 126.70, 126.24, 123.77, 123.16, 121.38, 117.80, 117.59, 115.88, 111.34, 47.82, 21.05. HR-MS (ESI, m/z): calc. for $\mathrm{C}_{33} \mathrm{H}_{29} \mathrm{~N}_{3} \mathrm{O}_{4} \mathrm{~S}$ $\left([\mathrm{M}+\mathrm{H}]^{+}\right) 564.1952$, found 564.1976. 


\section{Sepin-1}<smiles>CC1(C)N(O)c2cc([N+](=O)[O-])ccc2[N+]1=O</smiles>

${ }^{1} \mathrm{H}$ NMR (DMSO-d $\left.6,400 \mathrm{MHz}\right) \delta[\mathrm{ppm}]=8.03(\mathrm{t}, J=1.4 \mathrm{~Hz}, 1 \mathrm{H}), 7.55(\mathrm{dd}, J=10.1,1.8 \mathrm{~Hz}$, $1 \mathrm{H}$ ), 7.43 (dd, $J=10.1,1.0 \mathrm{~Hz}, 1 \mathrm{H}), 1.62(\mathrm{~s}, 6 \mathrm{H}) .{ }^{13} \mathrm{C}$ NMR (DMSO-d, $101 \mathrm{MHz}$ ) $\delta[p p m]=$ 147.87, 134.45, 134.17, 122.27, 116.18, 112.06, 97.62, 22.34. HR-MS (ESI, m/z): calc. for $\mathrm{C}_{9} \mathrm{H}_{9} \mathrm{~N}_{3} \mathrm{O}_{4}\left([\mathrm{M}+\mathrm{H}]^{+}\right)$224.0666, found 224.0683. 


\section{NMR Spectra}

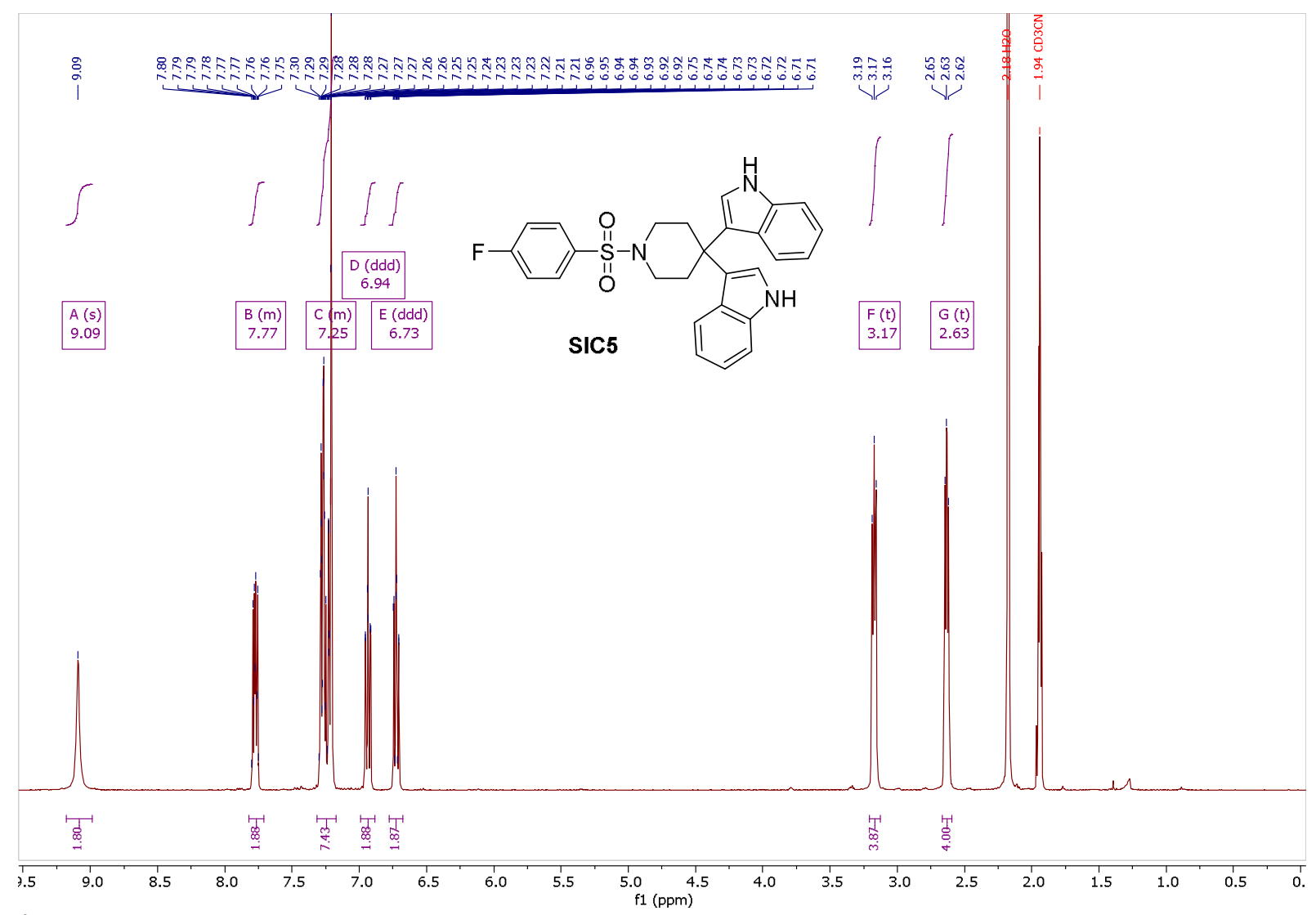

${ }^{1} \mathrm{H}$ NMR (MeCN-d $3,400 \mathrm{MHz}$ )

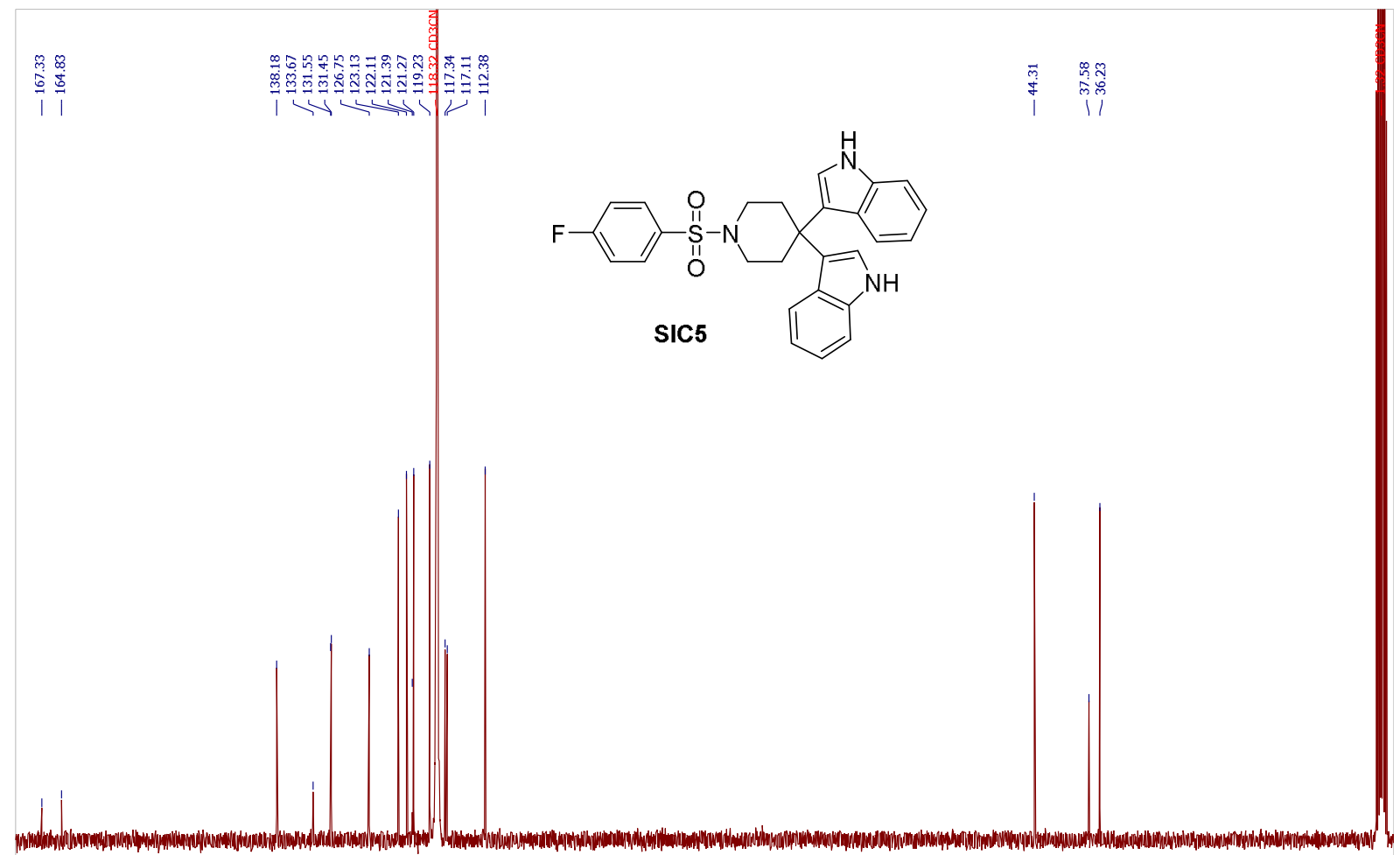

\begin{tabular}{rrrrrrr}
\hline 70 & 160 & 150 & 140 & 130 & 120 & 110
\end{tabular} ${ }_{90}^{10} 80$

${ }^{13} \mathrm{C}$ NMR (MeCN-d, $101 \mathrm{MHz}$ ) 


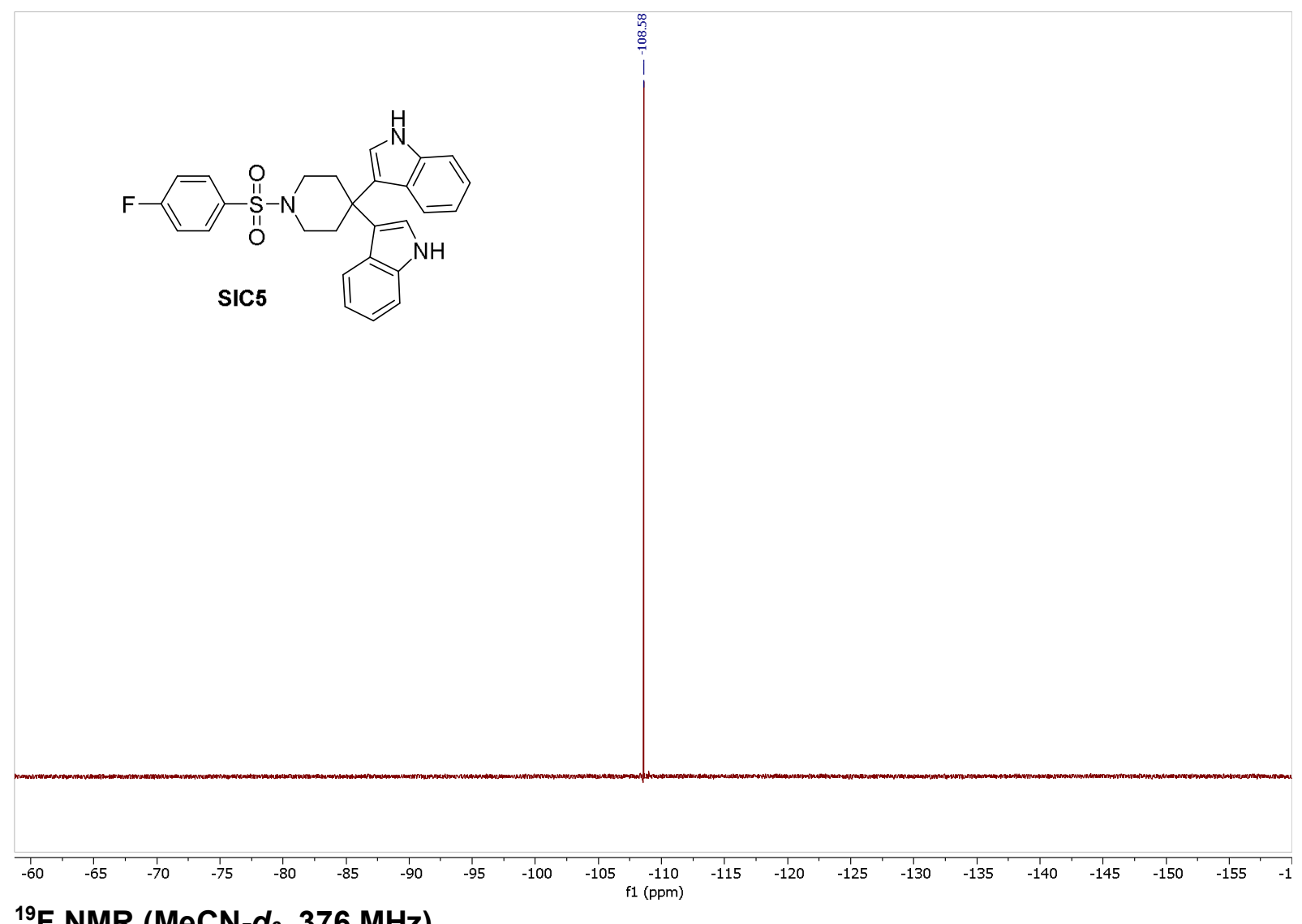

${ }^{19} \mathrm{~F} \mathrm{NMR}\left(\mathrm{MeCN}-d_{3}, 376 \mathrm{MHz}\right)$ 


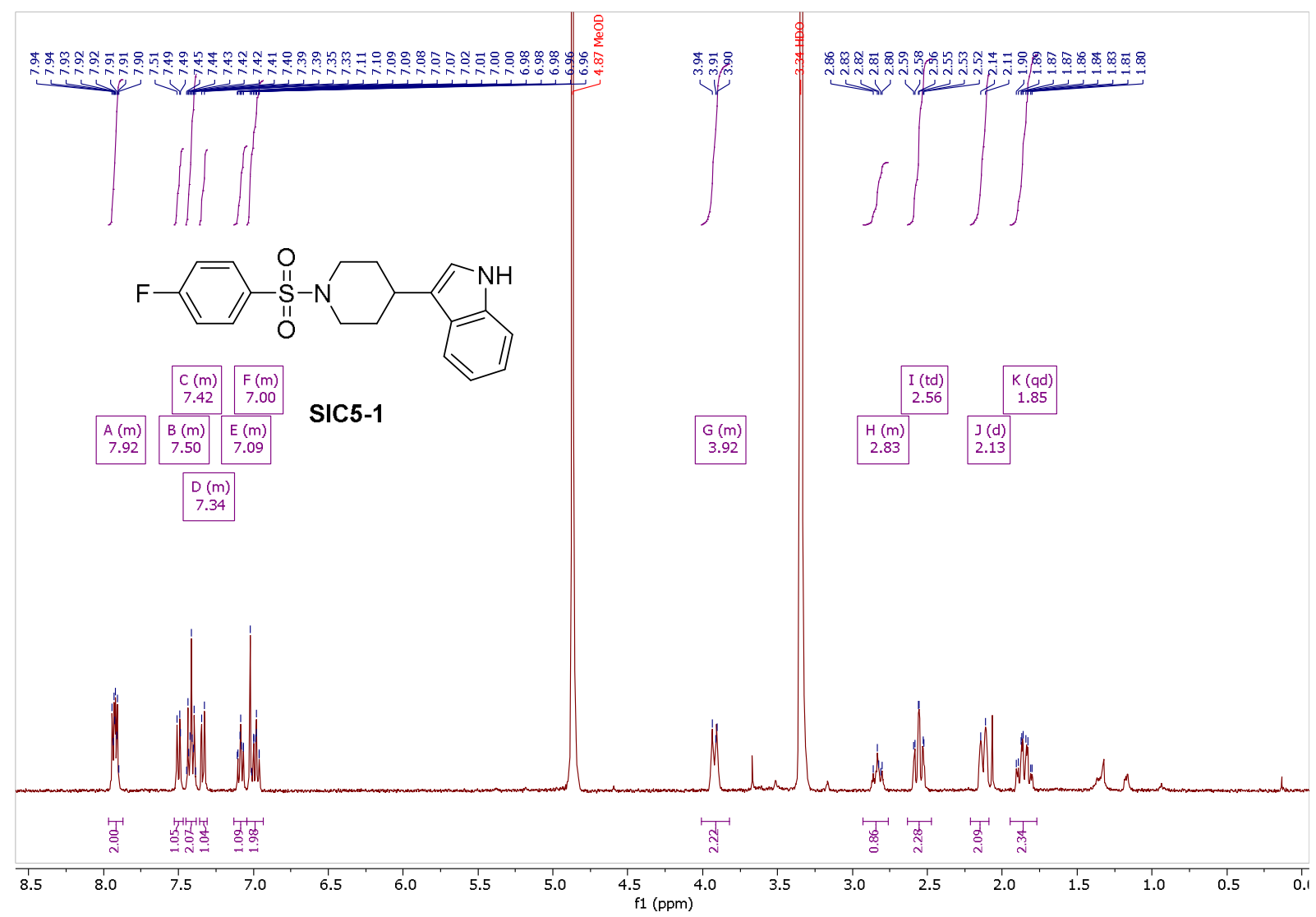

${ }^{1} \mathrm{H}$ NMR (MeOD-d 4,400 MHz)
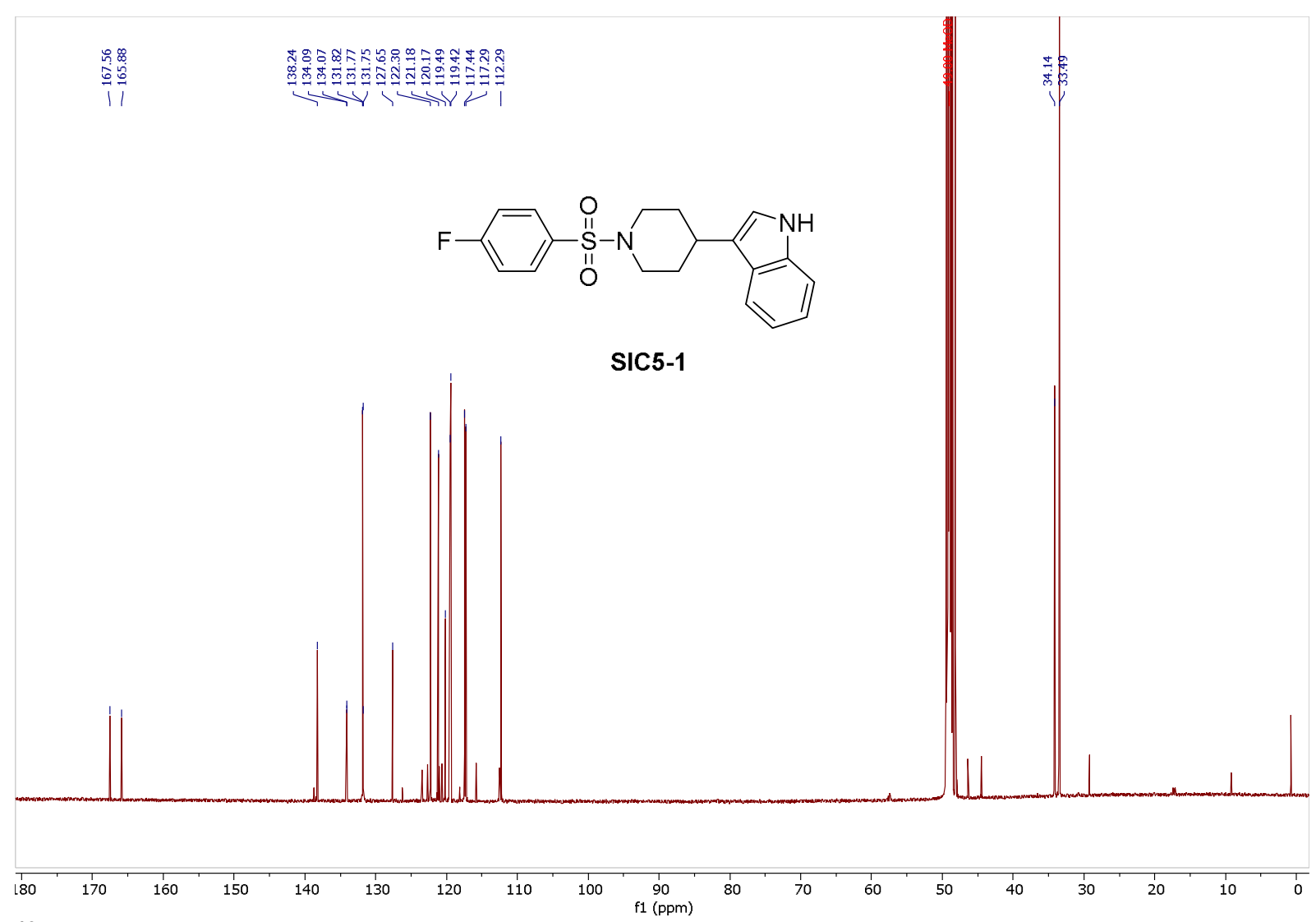

${ }^{13} \mathrm{C}$ NMR (MeOD- $d_{4}, 151 \mathrm{MHz}$ ) 


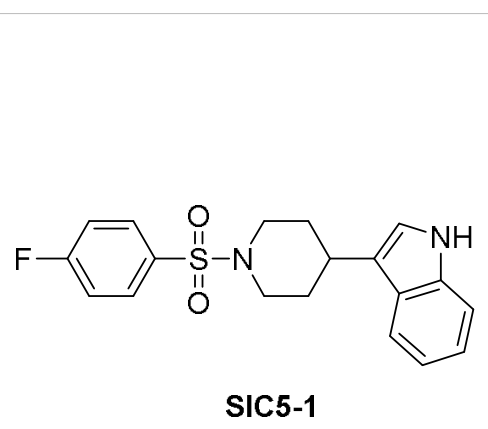

SIC5-1

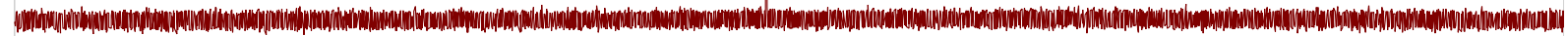

\begin{tabular}{rlllllllllllllllllll}
\hline-65 & -70 & -75 & -80 & -85 & -90 & -95 & -100 & -105 & -110 & -115 & -120 & -125 & -130 & -135 & -140 & -145 & -150 & -155 & -11 \\
\hline
\end{tabular}

${ }^{19} \mathrm{~F}$ NMR (MeOD- $\left.d_{4}, 376 \mathrm{MHz}\right)$ 


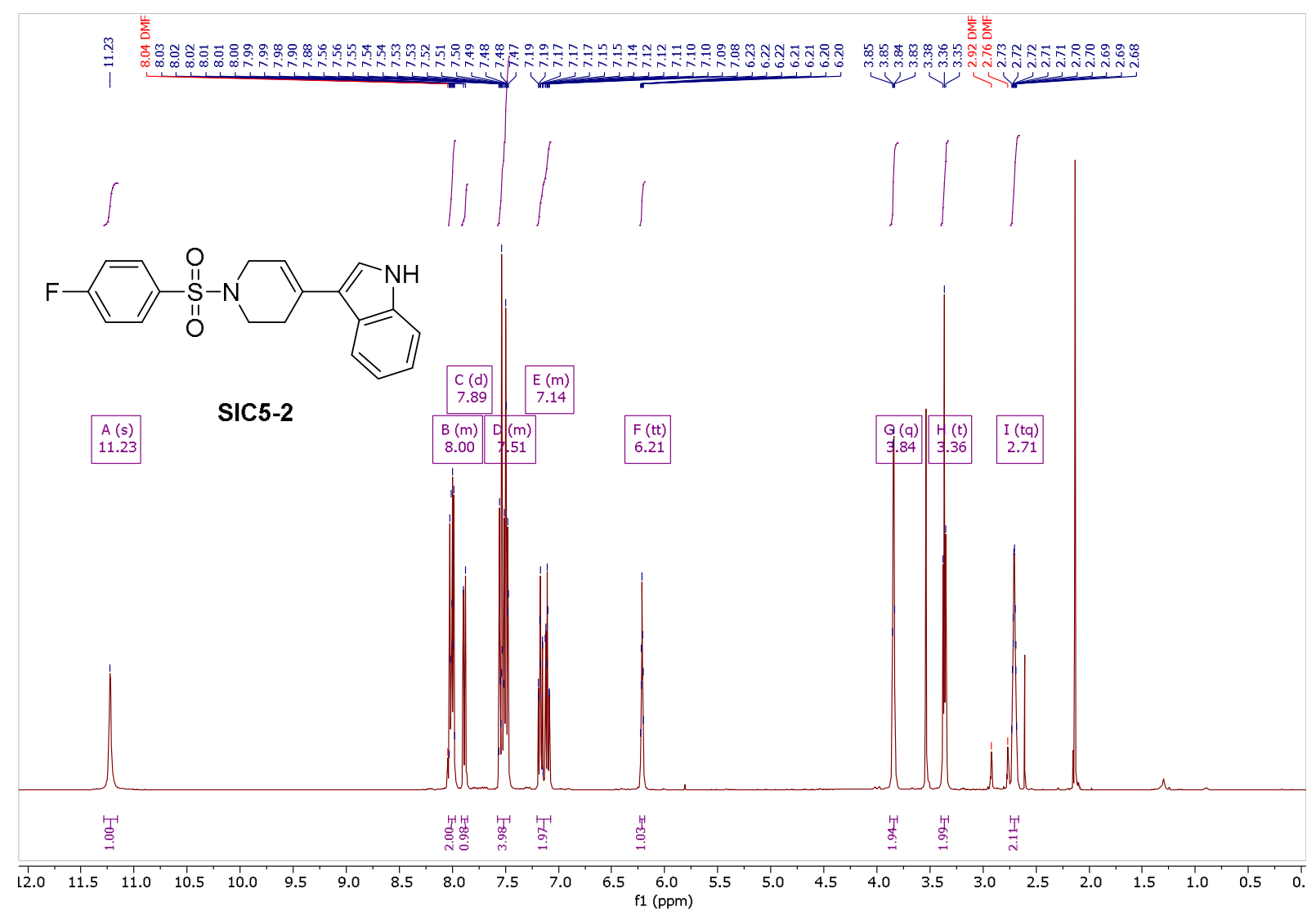

${ }^{1} \mathrm{H}$ NMR (DMF- $\left.d_{7}, 400 \mathrm{MHz}\right)$

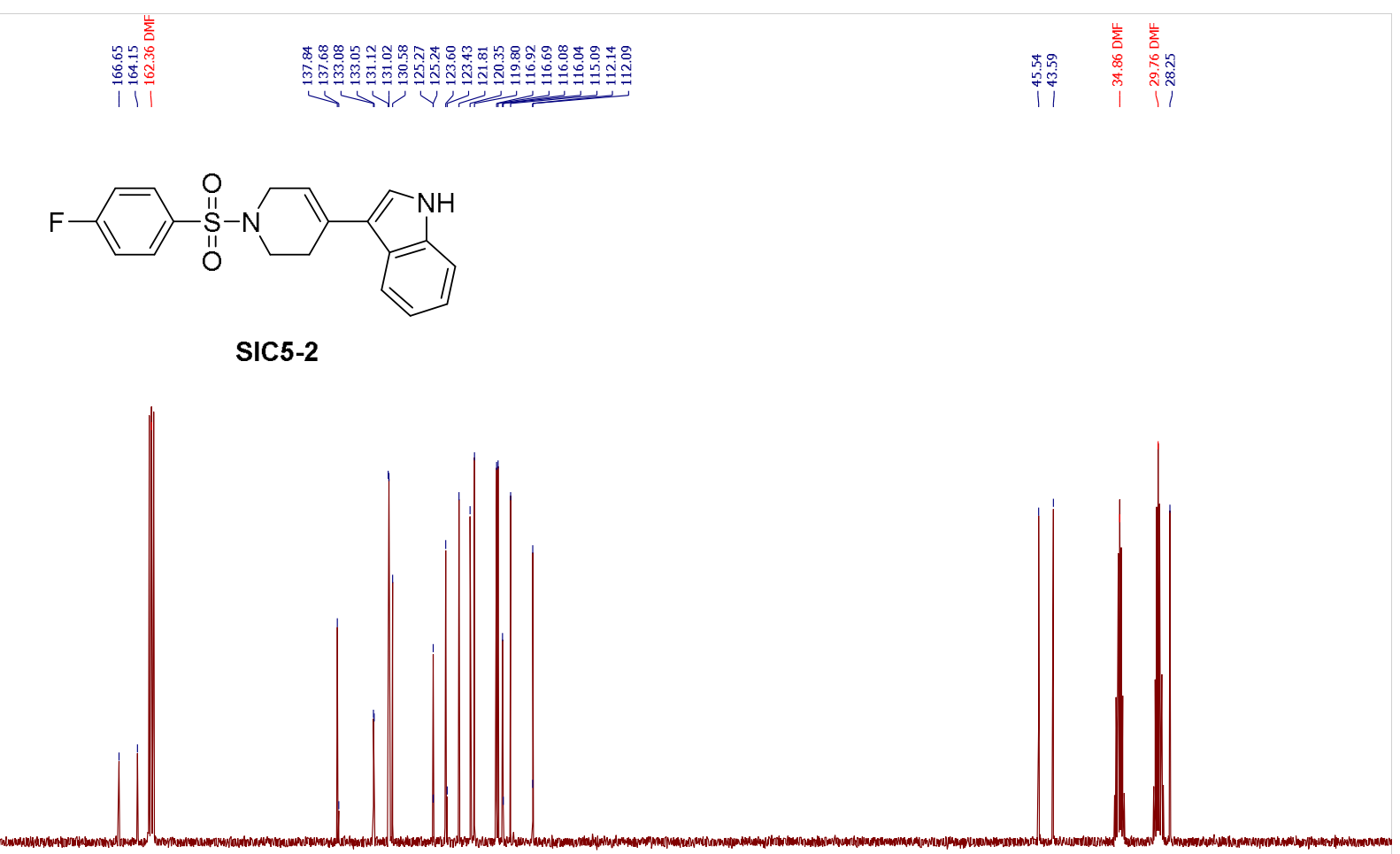

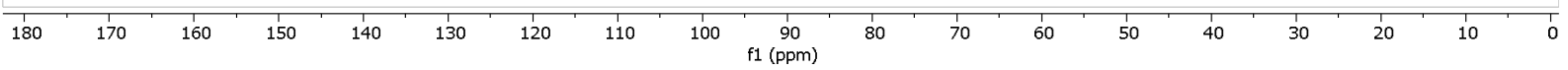

${ }^{13} \mathrm{C}$ NMR (DMF-d, $\left.101 \mathrm{MHz}\right)$ 


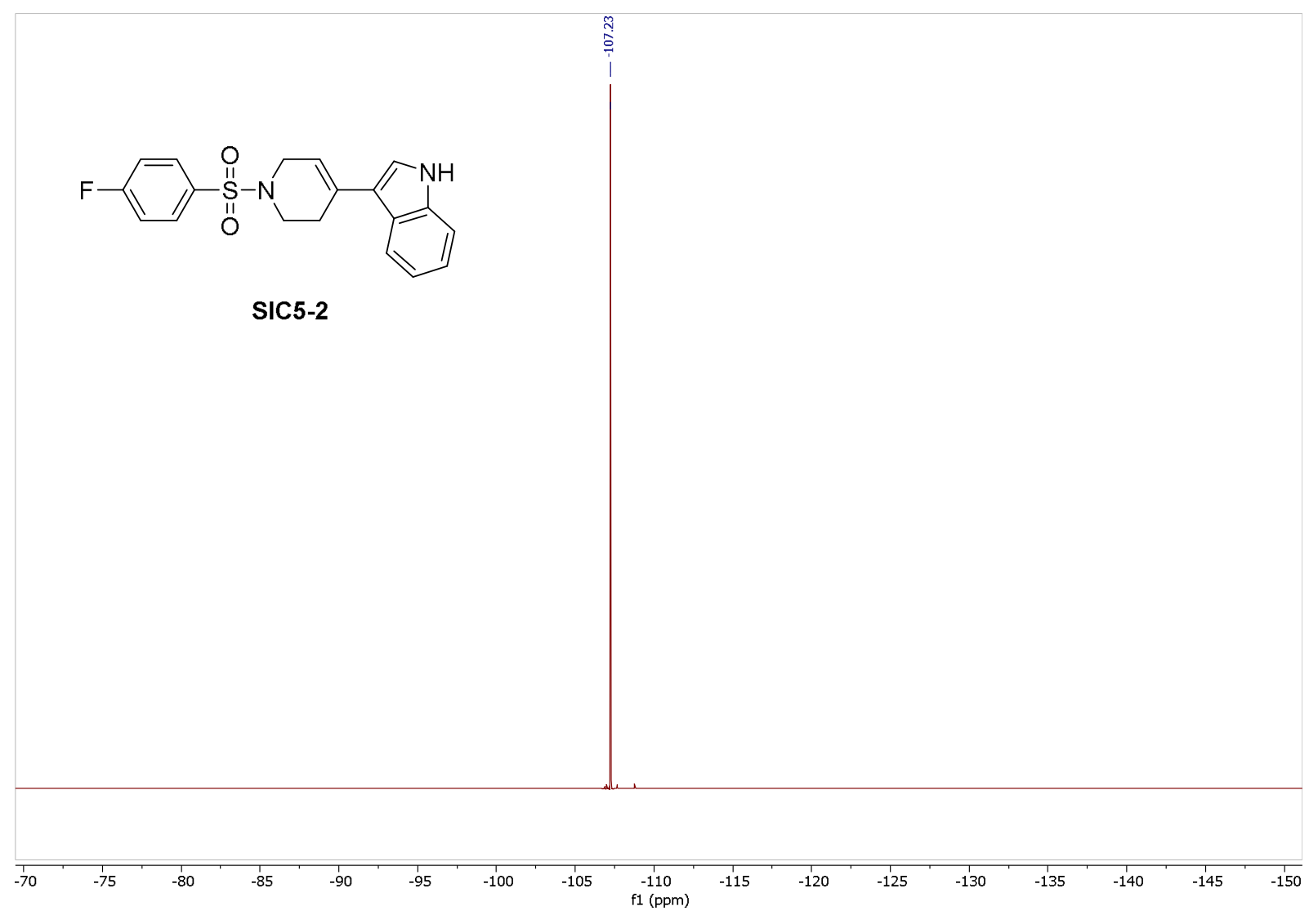

${ }^{19} \mathrm{~F}$ NMR (DMF- $d_{7}, 376 \mathrm{MHz}$ ) 


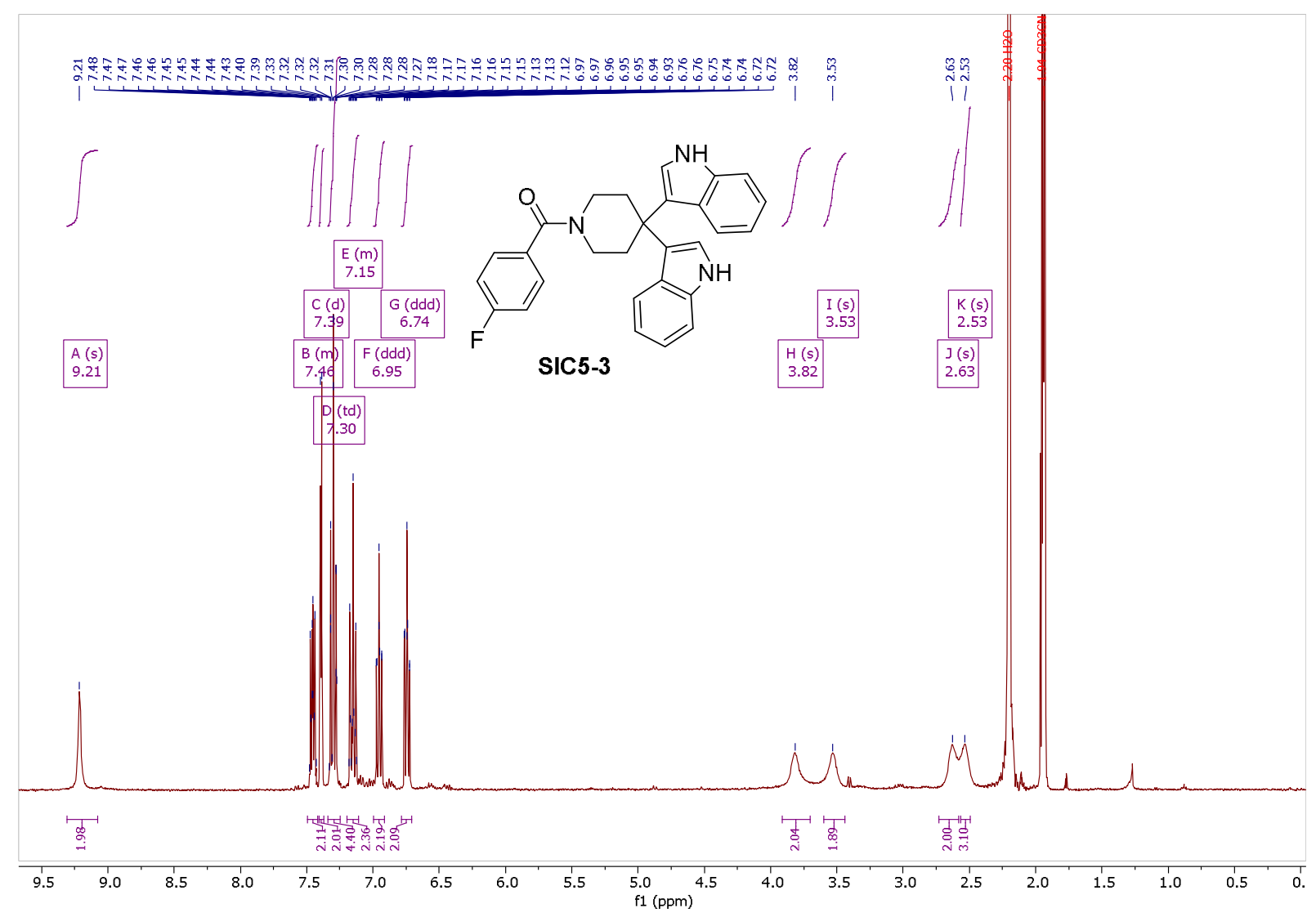

${ }^{1} \mathrm{H}$ NMR (MeCN-d $3,400 \mathrm{MHz}$ )

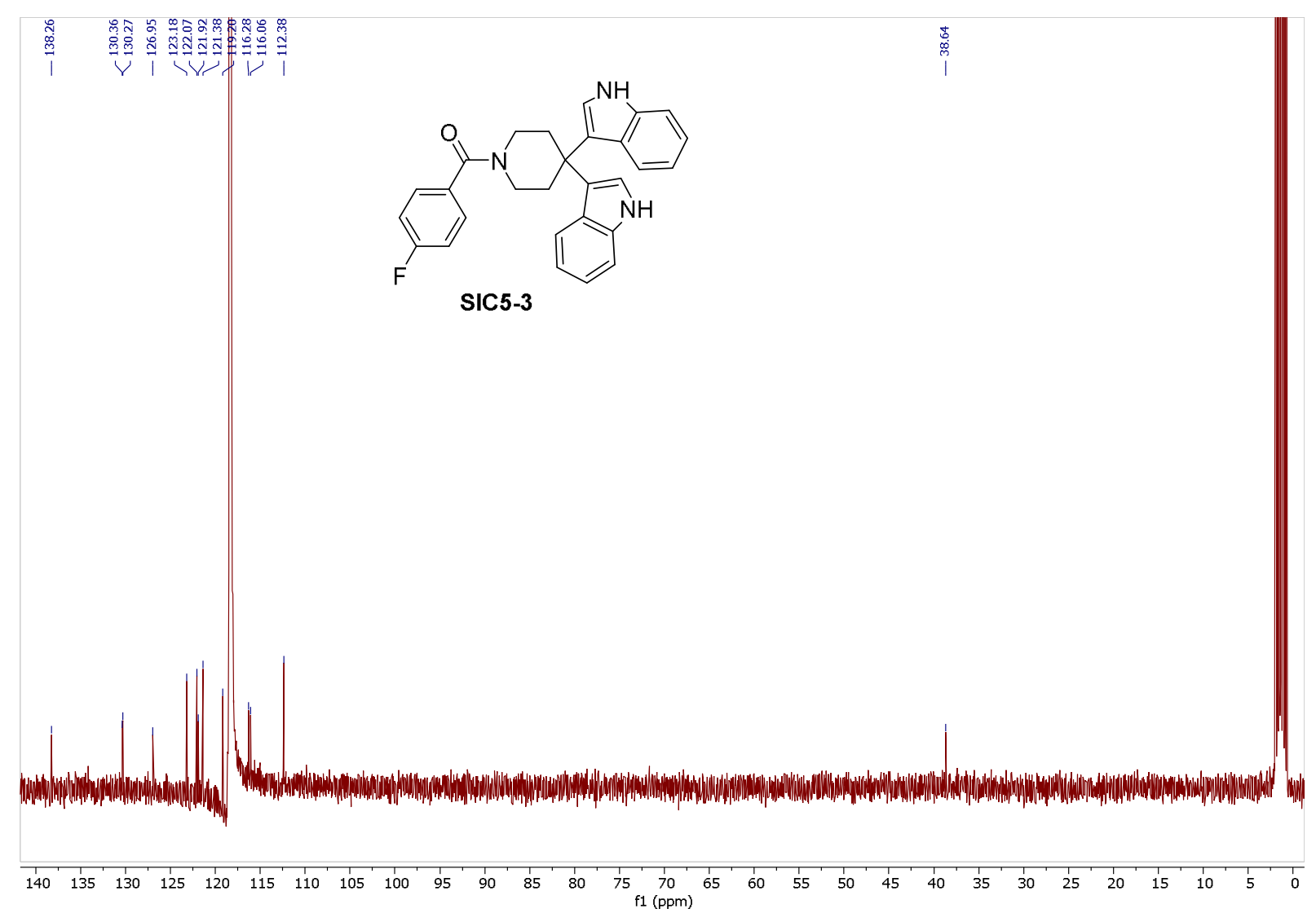

${ }^{13} \mathrm{C}$ NMR (MeCN-d $\left.3,101 \mathrm{MHz}\right)$ 
<smiles>CC(C)(C)c1ccccc1CC1(c2c[nH]c3ccccc23)CCN(C(=O)c2ccc(F)cc2)CC1</smiles>

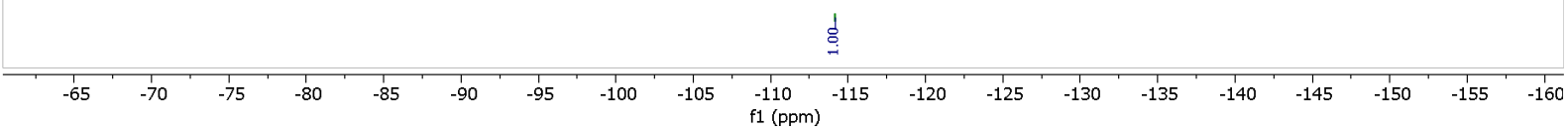

${ }^{19} \mathrm{~F}$ NMR $\left(\mathrm{MeCN}-d_{3}, 376 \mathrm{MHz}\right)$ 


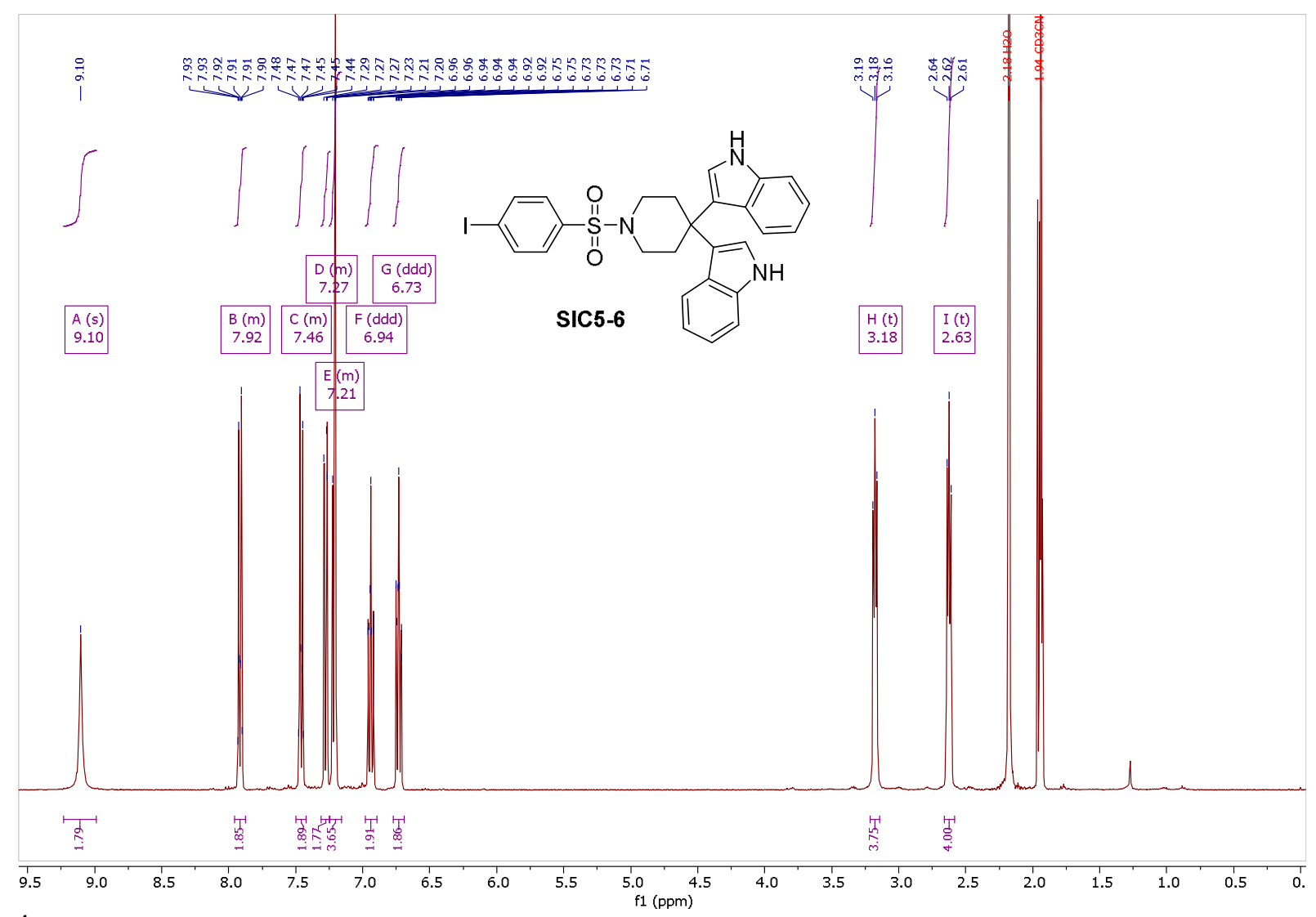

${ }^{1} \mathrm{H} \mathrm{NMR}\left(\mathrm{MeCN}-d_{3}, 400 \mathrm{MHz}\right)$

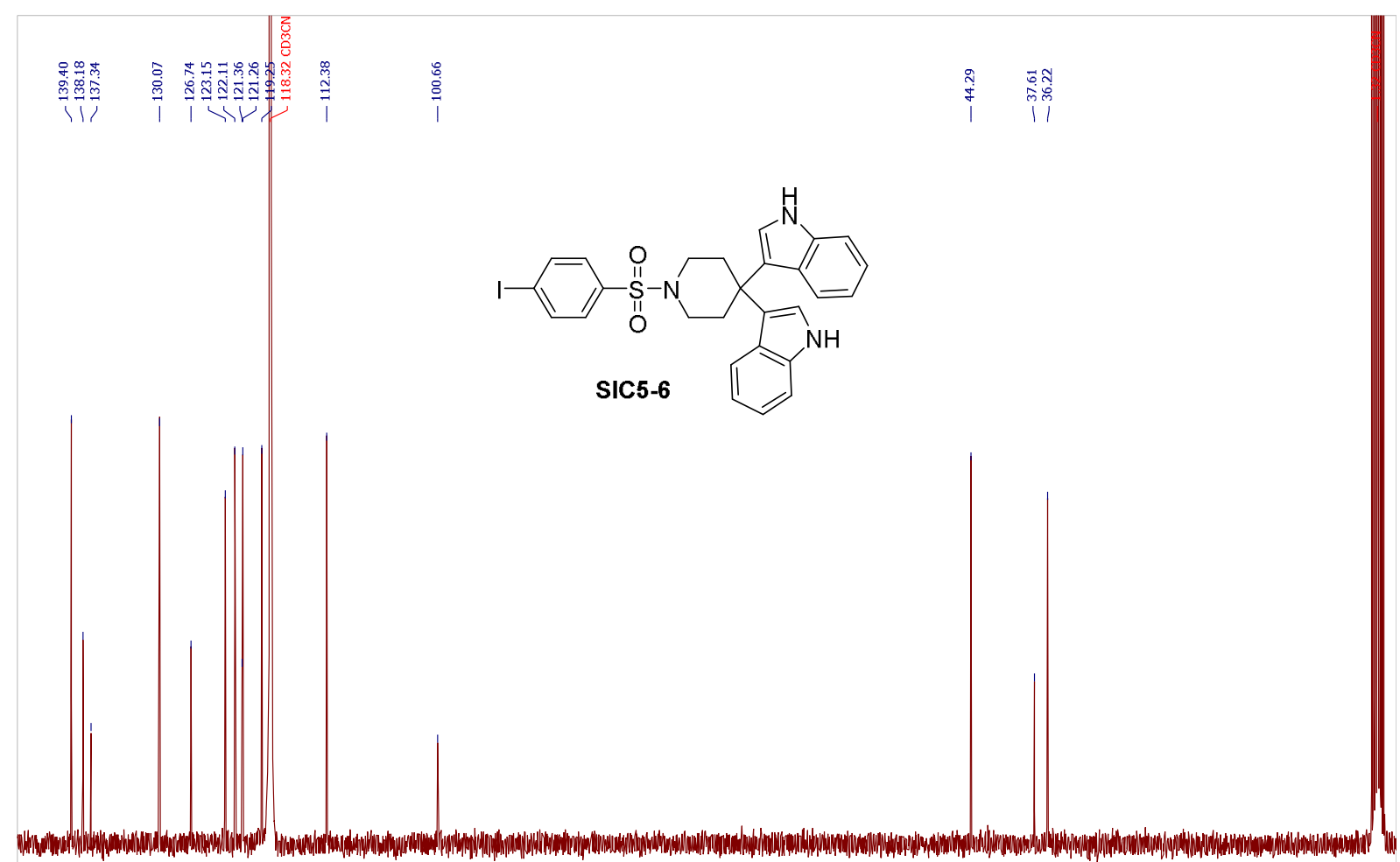

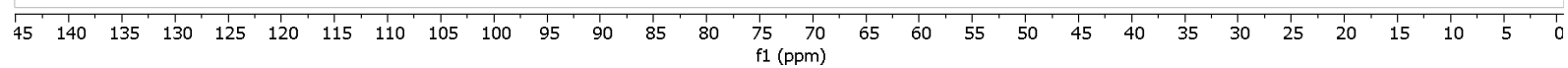

${ }^{13} \mathrm{C}$ NMR (MeCN-d $3,101 \mathrm{MHz}$ ) 


\section{References}

1. Hellmuth, S., Rata, S., Brown, A., Heidmann, S., Novak, B., and Stemmann, O. (2015) Human chromosome segregation involves multi-layered regulation of separase by the peptidyl-prolyl-isomerase Pin1, Molecular cell 58, 495-506.

2. Stemmann, O., Zou, H., Gerber, S. A., Gygi, S. P., and Kirschner, M. W. (2001) Dual inhibition of sister chromatid separation at metaphase, Cell 107, 715-726.

3. Rothbauer, U., Zolghadr, K., Muyldermans, S., Schepers, A., Cardoso, M. C., and Leonhardt, H. (2008) A versatile nanotrap for biochemical and functional studies with fluorescent fusion proteins, Molecular \& cellular proteomics : MCP 7, 282-289. 